\title{
Geochemistry and petrogenesis of post-collisional ultrapotassic syenites and granites from southernmost Brazil: the Piquiri Syenite Massif
}

\author{
LAURO V.S. NARDI ${ }^{1}$, JORGE PLÁ-CID ${ }^{2}$, MARIA DE FÁTIMA BITENCOURT ${ }^{1}$ and LARISSA Z. STABEL ${ }^{1}$ \\ ${ }^{1}$ Instituto de Geociências, UFRGS, Caixa Postal 15001, 91501-970 Porto Alegre, RS, Brasil \\ ${ }^{2}$ DNPM, Rua Alvaro Millen da Silveira, 151, 88020-180 Florianópolis, SC, Brasil \\ Manuscript received on January 17, 2006; accepted for publication on July 3, 2007; \\ contributed by LAURO V. S. NARDI*
}

\begin{abstract}
The Piquiri Syenite Massif, southernmost Brazil, is part of the post-collisional magmatism related to the Neoproterozoic Brasiliano-Pan-African Orogenic Cycle. The massif is about $12 \mathrm{~km}$ in diameter and is composed of syenites, granites, monzonitic rocks and lamprophyres. Diopside-phlogopite, diopside-biotite-augite-calcic-amphibole, are the main ferro-magnesian paragenesis in the syenitic rocks. Syenitic and granitic rocks are co-magmatic and related to an ultrapotassic, silica-saturated magmatism. Their trace element patterns indicate a probable mantle source modified by previous, subduction-related metasomatism. The ultrapotassic granites of this massif were produced by fractional crystallization of syenitic magmas, and may be considered as a particular group of hypersolvus and subsolvus A-type granites. Based upon textural, structural and geochemical data most of the syenitic rocks, particularly the fine-grained types, are considered as crystallized liquids, in spite of the abundance of cumulatic layers, schlieren, and compositional banding. Most of the studied samples are metaluminous, with $\mathrm{K}_{2} \mathrm{O} / \mathrm{Na}_{2} \mathrm{O}$ ratios higher than 2. The ultrapotassic syenitic and lamprophyric rocks in the Piquiri massif are interpreted to have been produced from enriched mantle sources, OIB-type, like most of the post-collisional shoshonitic, sodic alkaline and high-K tholeiitic magmatism in southernmost Brazil. The source of the ultrapotassic and lamprophyric magmas is probably the same veined mantle, with abundant phlogopite + apatite + amphibole that reflects a previous subduction-related metasomatism.
\end{abstract}

Key words: post-collisional magmatism, ultrapotassic syenites, ultrapotassic granites, A-type magmatism, Piquiri Syenite Massif.

\section{INTRODUCTION}

Syenitic or trachytic magmas can occur in the silicaundersaturated or saturated alkaline igneous series (Lameyre and Bowden 1982). Silica-saturated syenites and trachytes can be related to the sodic $\left(\mathrm{Na}_{2} \mathrm{O} / \mathrm{K}_{2} \mathrm{O}>2\right.$; Le Maitre 2002) and shoshonitic series $\left(\mathrm{Na}_{2} \mathrm{O} / \mathrm{K}_{2} \mathrm{O} \approx\right.$ 1; Morrison 1980). Nevertheless, plagioclase-bearing syenites and trachytes having $\mathrm{K}_{2} \mathrm{O} / \mathrm{Na}_{2} \mathrm{O}$ higher than 2 are among the most abundant types of syenitic rocks, and are frequently associated with ultrapotassic lampro-

* Member Academia Brasileira de Ciências

Correspondence to: Lauro Valentim Stoll Nardi

E-mail: lauro.nardi@ufrgs.br phyres. They have been reported by several authors (e.g. Holm et al. 1982, Thompson and Fowler 1986, Laflèche et al. 1991, Corriveau and Gorton 1993, Janasi et al. 1993, Eklund et al. 1998, Stabel et al. 2001), particularly in one of the largest syenitic provinces in the world, situated in northeastern and eastern Brazil (e.g. Silva Filho et al. 1987, Ferreira and Sial 1993, Conceição 1993, Conceição et al. 1997, Plá Cid et al. 1999, Conceição et al. 2000a). Even though some authors (e.g. Rogers 1992) consider that shoshonitic and ultrapotassic lavas should not be distinguished, since "both types coexist in the same volcano", shoshonitic and ultrapotassic syenites have significant compositional and miner- 
alogical differences, as recognized by Silva Filho et al. (1987), Ferreira and Sial (1993) and Conceição et al. (2000b) among other authors. According to Plá Cid et al. (2000) the alkaline ultrapotassic association defined by Foley et al. (1987) should include the more differentiated intermediate and acid rocks with $\mathrm{MgO}$ content under 3 wt. $\%$, and $\mathrm{K}_{2} \mathrm{O} / \mathrm{Na}_{2} \mathrm{O}$ ratios over 2. Additionally, the shoshonitic series corresponds to the latitic or monzonitic series of Tauson (1983) where, as reported by Lameyre and Bowden (1982), monzonites and quartzmonzonites are the typical and characteristic intermediate plutonic rocks. The presence of syenites and quartzsyenites in the shoshonitic series should be more thoroughly investigated. Some of the so-called shoshonitic syenites may be K-feldspar cumulates, and others would be better classified as differentiates belonging to the alkaline, silica-saturated sodic or ultrapotassic magmatic series.

Syenites and trachytes, according to Thompson and Fowler (1986), are relatively rare rock types that occur mostly in ocean-island and continental rift-related suites, and more rarely in orogenic belts. In the last two decades the importance of syenites and trachytes in post-collisional or post-orogenic settings, where the mantle sources were affected by a previous subduction, has been strongly emphasized. Potassic and ultrapotassic syenitic or trachytic rocks from post-orogenic or postcollisional settings have been described by several authors (e.g. Civetta et al. 1981, Holm et al. 1982, Thompson and Fowler 1986, Silva Filho et al. 1987, Nardi and Bonin 1991, Ferreira and Sial 1993, Conceição 1993, Conceição et al. 1997, 2000a, Eklund et al. 1998, Plá Cid et al. 1999, Sommer et al. 1999, Wildner et al. 1999, Miller et al. 1999, Stabel et al. 2001, Ilbeyli et al. 2004), and in some Archaean terranes (Laflèche et al. 1991, Bourne and L'Heureux 1991, Corriveau and Gorton 1993). Pliocene ultrapotassic lavas and minettes in a typical post-collisional setting have been described in Sierra Nevada, California, by Feldstain and Lange (1999).

Potassic (or shoshonitic) and ultrapotassic magmatism are frequently associated, either in volcanic sequences like the Roman Province (Civetta et al. 1981) or the Aeolian arc (De Astis et al. 2000), or in plutonic associations, such as those referred by Silva et al. (1987,
1993 ) and Thompson and Fowler (1986). In many cases, they are related to minettes (Leat et al. 1989, Conceição et al. 1997, Stabel et al. 2001, Paim et al. 2002, Plá Cid et al. 2005, among other authors).

Melting of mantle portions composed mainly of clinopyroxene \pm hydrated minerals is largely accepted for the origin of potassic and ultrapotassic magmas (e.g. Lloyd et al. 1985, Foley et al. 1987). Carmichael et al. (1996) described minettes and associated shoshonitic volcanic rocks from Mascota, western Mexico, and proposed that they derive from melting of phlogopite + apatite lherzolites. Shoshonitic basaltic and andesitic melts $-\mathrm{K}_{2} \mathrm{O} / \mathrm{Na}_{2} \mathrm{O}$ about 1 - can be produced by decompression melting of a metasomatized mantle containing low amounts of phlogopite and pargasite, as demonstrated by Conceição and Green (2004). The generation of bimodal associations of syenites and more differentiated, co-magmatic rocks from primary intermediate magmas of monzonitic composition was proposed by Bonin and Giret (1984) for the Oslo plutonic province. The importance and viability of intermediate primary magmas are enhanced by the experimental work of Conceição and Green (2004). Alternatively, the derivation of potassic and ultrapotassic trachytes and syenites from magmas of minette compositions are suggested by several authors, such as Thompson and Fowler (1986), Rock (1987), Leat et al. (1989), Janasi et al. (1993), Conceição et al. (2000a), and Plá Cid et al. (2005).

This paper is focused on the whole-rock geochemistry of the Piquiri Syenite Massif - a Neoproterozoic post-collisional association of ultrapotassic syenites, quartz-syenites and granites containing mafic microgranular enclaves of minette composition. Previous studies (Plá Cid et al. 2003, 2005) have proposed that the minette enclaves were generated by melting of a lherzolitic veined mantle, with phlogopite and apatite, under pressures over $3 \mathrm{GPa}$. A similar source is here proposed for the primary intermediate melts that generated the syenitic and granitic rocks of Piquiri Massif.

\section{Geological Setting}

Shield areas in southern Brazil (Fig. 1) are composed mostly of magmatic rocks, related to the Brasiliano-PanAfrican Cycle, emplaced in a metamorphic basement of Paleoproterozoic age (Hartmann et al. 1999, Soliani 


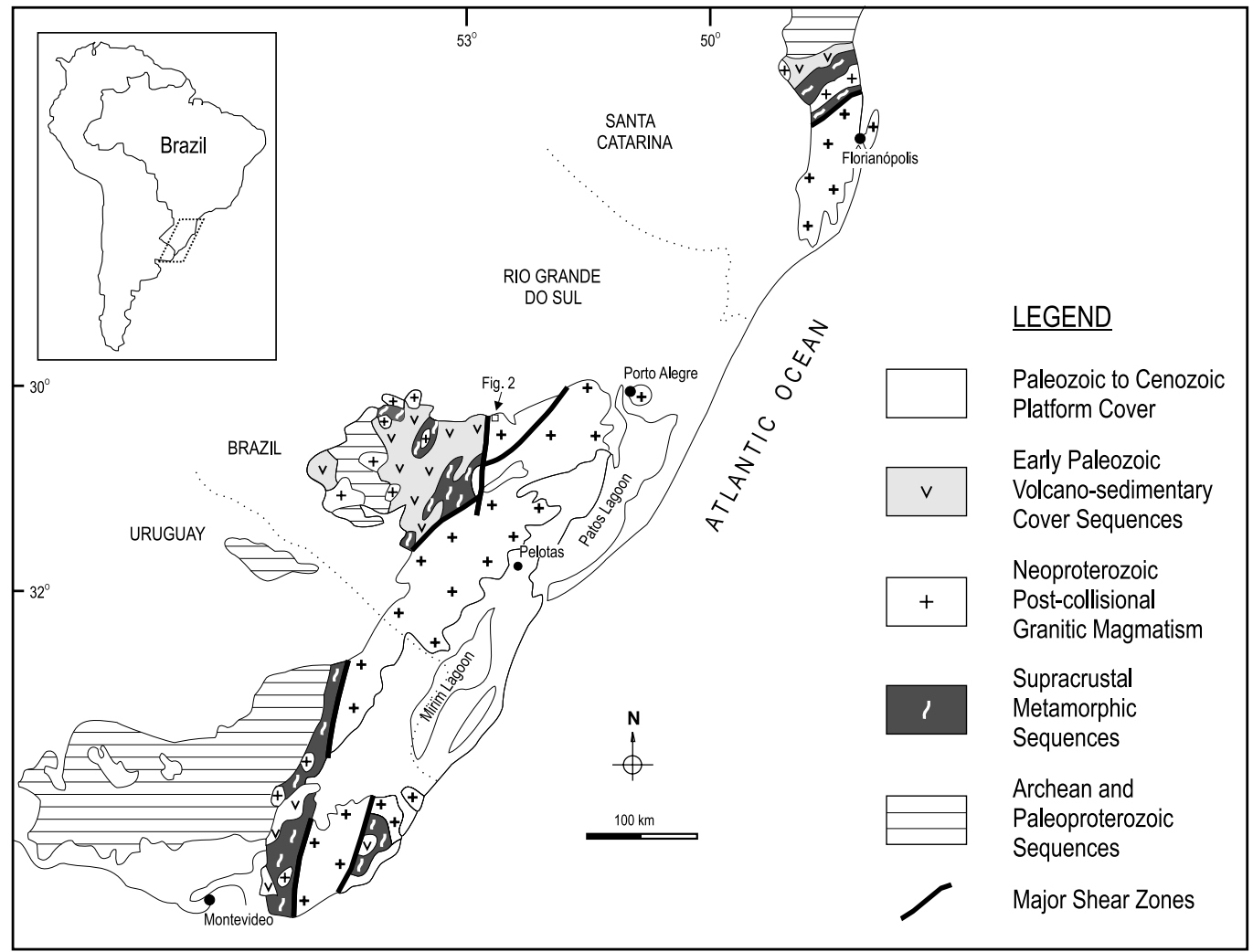

Fig. 1 - Geological context of southernmost Brazil.

Jr. et al. 2000). The Brasiliano-Pan-African Cycle is marked by arc magmatism with ages mainly from 700 to $760 \mathrm{Ma}$ (Fernandes et al. 1992, Babinski et al. 1997, Chemale Jr. 2000) and a widespread post-collisional magmatism (in the sense of Liégeois 1998), with ages from 550 to $650 \mathrm{Ma}$ (Bitencourt and Nardi 2000).

The post-collisional stage in the eastern portion of this region is marked by voluminous magmatism along the transcurrent lithospheric discontinuities of the Southern Brazilian Shear Belt (Bitencourt and Nardi 2000) which has led to the construction of the Pelotas Batholith (Philipp et al. 2002). The syntectonic magmatism includes early, high-K calc-alkaline granitoids and leucocratic peraluminous granites, granitoids of shoshonitic affinity and, eventually, late to post-transcurrence, dominantly metaluminous, alkaline granites. Except for the leucocratic peraluminous granites, all granitoid types are associated with coeval basic magmas represented by mafic microgranular enclaves, dikes, and mafic components in co-mingling systems.
The western and northwestern portions represent less deformed areas, where extensional tectonics and the generation of strike-slip basins were predominant. Volcano-sedimentary sequences were deposited during this time interval and intruded by plutonic associations following the same geochemical patterns observed in the eastern part. High-K calc-alkaline granitoids, K-rich tholeiitic mafic magmas, shoshonitic plutono-volcanic associations, and silica-saturated, alkaline to continental tholeiitic plutono-volcanic sequences vary in age from ca. 650 to $570 \mathrm{Ma}$. Plutonic and volcanic acid to basic rocks of shoshonitic affinity are widespread in the 610590 Ma age interval (Lima and Nardi 1998a), and are followed by (i) voluminous sodic, silica-saturated alkaline magmatism, the Saibro Intrusive Suite (Nardi and Bonin 1991), mostly composed of metaluminous granites, with minor peralkaline components, and (ii) large volcanic plateaus where acid lavas and pyroclastics are dominant, with minor intermediate and basic components (Sommer et al. 1999, Wildner et al. 1999). 


\section{GEOLOGY OF THE PIQUIRI SYENITE MASSIF}

The Piquiri Syenite Massif is a roughly semi-circular pluton (Fig. 2), approximately $150 \mathrm{Km}^{2}$ in area, situated in the central-northern part of the Sul-rio-grandense Shield (Jost et al. 1985). It is partly surrounded by metamorphic rocks and intruded by the Encruzilhada Granitic Complex. This complex, dated at $593 \pm 5 \mathrm{Ma}$ (U-Pb in zircon-Babinski et al. 1997), is considered part of the post-collisional Brasiliano Cycle magmatism, and includes metaluminous granitoids related to the silicasaturated alkaline series. The northwestern contact of the syenitic massif, with Neoproterozoic and Paleozoic Camaquã Basin sedimentary sequences, is largely tectonic.

Age determinations on the Piquiri syenites produced values of $615 \pm 99 \mathrm{Ma}$ (Rb-Sr whole-rock - Soliani Jr et al. 2000), and $611 \pm 3 \mathrm{Ma}$ (Pb-Pb data on magmatic zircons - Philipp et al. 2002).

The massif is composed of: (i) medium- to coarsegrained alkali feldspar syenites, which predominate in the inner portions of the intrusion; (ii) fine- to mediumgrained syenites to quartz-monzonites, mainly in the pluton borders; (iii) phlogopite-bearing alkali feldspar syenites, which show mingling features with the alkali feldspar syenites; (iv) syenogranites and alkali feldspar granites, which occur mainly in the central part of the pluton, and (v) several types of enclaves.

Internal contacts among the four dominant rock types are generally gradational and suggest that their crystallization was approximately synchronous. Granites represent the last crystallized liquids, crosscutting internal contacts or containing syenitic autoliths.

A magmatic flow foliation is present in all the syenitic rocks, best developed in the coarser-grained alkali feldspar syenites of the pluton center. The finer-grained rocks of the pluton margins have variably-developed orientation intensity. The foliation is marked by wellaligned K-feldspar crystal faces and enhanced by mafic aggregates. No preferential linear alignment is visible. Compositional banding is an early-formed structural feature, and the main foliation is oriented either parallel to or at high angles with it. The mafic layers, often composed of coarse- to very coarse-grained cumulus pyroxenes and amphiboles, are either continuous or disrupted, giving rise to schlieren layering. The seg- regational character of such layers is enhanced by the presence of country-rock xenoliths, chilled-margin fragments, mafic cumulatic autholiths, and microgranular mafic enclaves. There is no evidence of solid-state deformation.

The fine- to medium-grained syenites and quartzmonzonites are petrographically distinct from the dominant alkali feldspar syenites due to their finer texture, to the presence of quartz and preserved plagioclase crystals, and potassic feldspar with perthite contents lower than $25 \mathrm{vol} \%$ (Stabel et al. 2001). Diopside is the dominant pyroxene, whilst in the dominant alkali feldspar syenites, augite is more abundant. The dominant alkali feldspar syenites are leucocratic to mesocratic rocks, whilst the fine- to medium-grained varieties are mostly mesocratic. Plagioclase from the alkali feldspar syenites occurs mostly as partially resorbed inclusions in alkali feldspar, as discussed by Nekvasil (1990) for similar syenitic compositions. Stabel et al. (2001) interpreted the fine- to medium-grained rocks as co-magmatic with the alkali feldspar syenites, resulting from rapidlycrystallized liquids of compositions close to the parental magma. The phlogopite-bearing alkali feldspar syenites were found in drill cores, intimately associated with lamprophyric rocks.

Two types of granites are exposed in about $20 \%$ of the Piquiri Syenite Massif area, mostly in the core of the intrusion, and probably close to its roof, as indicated by gently-dipping magmatic-flow foliation (Fig. 2). The most abundant is a medium-grained amphibole-bearing alkali feldspar granite, sometimes grading to quartzsyenite, texturally very similar to the main alkali feldspar syenite. Syenogranites occur as small plutons or dykes crosscutting the syenitic host, sometimes containing syenitic enclaves.

Five distinct types of enclaves are found in the syenitic rocks: (i) mafic microgranular enclaves of dioritic composition; (ii) cumulatic autholiths composed of early-crystallized pyroxene and mica; (iii) fragments of syenitic chilled margins; (iv) xenoliths of metamorphic rocks; (v) swarms of a second type of lamprophyric mafic microgranular enclaves interpreted by Vieira Jr. et al. (1989) as products of co-mingling between the host syenite magma and a lamprophyric one. Plá Cid et al. (2003) interpreted these lamprophyric MME as related to an 


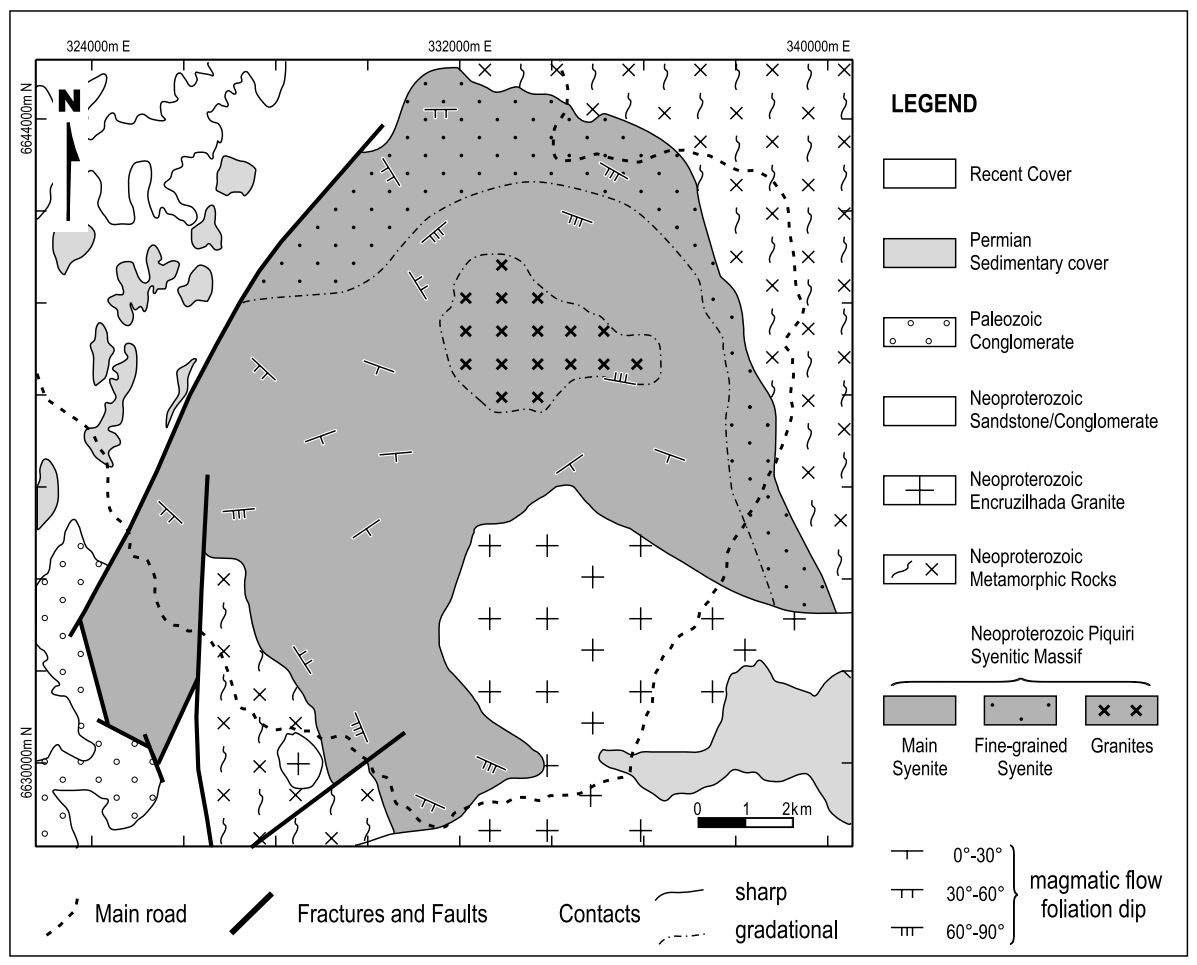

Fig. 2 - Geological map of Piquiri Syenite Massif.

ultrapotassic magma, compositionally close to minettes, produced by melting of a phlogopite-bearing mantle under pressures about $5 \mathrm{GPa}$. The presence of inclusions in pyroxenes, such as magmatic, potassium-rich pyroxenes, and pyrope-rich garnet containing $\mathrm{Na}$ and $\mathrm{K}$ (Plá Cid et al. 2003, 2005), are the main evidences for such deep sources.

\section{TEXTURAL AND MINERALOGICAL FEATURES}

The chemistry of minerals from the Piquiri Syenite Massif, here summarized, is based mainly on Stabel et al. (2001). Data about the lamprophyric enclaves, including geochemistry of rocks and minerals, are presented and discussed by Plá Cid et al. (2003) and Nardi et al. (2007).

The fine- to medium-grained syenite, interpreted as a rapidly-crystallized border facies, has diopside as the main ferromagnesian phase, followed by magnesium hornblende, edenite and low amounts of biotite. Plagioclase - $\mathrm{An}_{21-50}$ - is an early-crystallized phase and occurs also as inclusions in the major phases. Alkali feldspar contains variable amount of perthite, generally less than
20 vol. $\%$ of albite.

The medium- to coarse-grained alkali feldspar syenites have larger amounts of augite, edenite and magnesium hornblende; early-crystallized diopside is rarely found. Perthitic feldspar has more than 25 vol.\% albite, and sometimes forms mesoperthites. It contains partially resorbed inclusions of plagioclase.

Along with magmatic differentiation in the massif, pyroxene evolves from diopside to augite with increasing ferrosilite contents. Small amounts of $\mathrm{K}_{2} \mathrm{O}-0.19$ to $0.35 \mathrm{wt} . \%$ - were found in rare diopside grains, which can be interpreted as xenocrysts derived from the lamprophyric magma. The presence of K-bearing clinopyroxene is taken as evidence that the syenitic magma crystallization started under pressures higher than $3 \mathrm{GPa}$ (Plá Cid et al. 2003, 2005). $\mathrm{Mg} /(\mathrm{Mg}+\mathrm{Fe})$ ratios of ferromagnesian phases are higher in the more differentiated, medium- to coarse-grained syenites, which has been interpreted as due to increasing oxygen fugacity during magmatic differentiation.

Amphiboles are magnesium hornblende and edenite that evolved to Si-enriched compositions in the more 
differentiated alkali feldspar syenites. Late-crystallized actinolite may partially replace the ferromagnesian minerals. $\mathrm{Fe} /(\mathrm{Fe}+\mathrm{Mg})$ ratios around 0.7 are similar to those described in amphiboles from shoshonitic rocks (Lima and Nardi 1998b). The compositional evolution of amphiboles in the Piquiri Massif is similar to that of shoshonitic rocks or potassic and ultrapotassic syenites, such as the Santanápolis Syenite (Conceição et al. 1997).

Mica occurs as an early-crystallized phase particularly in the phlogopite-bearing alkali feldspar syenites. Early-crystallized biotite has $\mathrm{Fe} /(\mathrm{Fe}+\mathrm{Mg})$ ratios about 0.45 and plots in the field of micas from magnesian subalkaline or shoshonitic rocks, according to the parameters used by Nachit et al. (1985). Micas from the alkali feldspar syenites are more magnesian $-\mathrm{Fe} /(\mathrm{Fe}+\mathrm{Mg})$ $\sim 0.3$ - have lower Ti contents and plot in the field of biotite or phlogopite from alkaline rocks.

Ilmenite, magnetite, fluor-apatite, titanite, and zircon are the main accessory phases.

Textural relations indicate that the syenitic magma crystallized apatite, magnesian biotite or phlogopite, zircon, diopside and plagioclase in the early magmatic stages, followed by alkali feldspar and augite. Calcic amphibole, Fe-Ti oxides, titanite, and quartz are latecrystallized phases, followed by subsolidus biotite, actinolite, carbonates, fluorite and sulfides.

Alkali feldspar granites are medium-grained, heterogranular hypidiomorphic rocks, and have the same mineral phases observed in the alkali feldspar syenites. Titanite, amphibole and biotite are the most abundant mafic phases. The syenogranites are fine- to mediumgrained, heterogranular hypidiomorphic rocks, and their alkali feldspar has less than 10 vol.\% of fine perthites. Small amounts of biotite, amphibole, apatite, and zircon are found.

\section{GEOCHEMISTRY OF THE PIQUIRI SYENITE MASSIF}

Major and trace element contents, including rare earth elements, of 31 samples of the Piquiri Syenite Massif are listed in Tables I and II. Major and trace element were determined at Actlabs, Canada, by ICP/OES and ICP/MS, respectively, after metaborate/tetraborate fusion. Part of the samples were analyzed also in the laboratories of the Instituto de Geociências-UFRGS by X-ray fluores- cence (major and trace elements - $\mathrm{Ba}, \mathrm{Sr}, \mathrm{Rb}, \mathrm{Zr}$ ) and the results were coherent. A precision better than $2 \%$ was obtained for major elements, and better than $10 \%$ for trace elements. Analytical procedures followed the classical standards as referred by Jeffery and Hutchison (1981).

\section{Cumulates or Melts?}

The presence of several structures related to processes of magmatic mineral segregation and accumulation, even in those rocks that are not stricto sensu cumulates, requires an investigation of compositional variations related to these features. As discussed in Bitencourt and Nardi (2004), the effects of these magmatic-flow controlled processes can be detected based on field, petrographic and geochemical integrated studies, thus contributing to the definition of the composition of parental magmas and their co-magmatic liquids.

The behavior of syenitic samples in the following geochemical and petrological diagrams suggests their similarity with trachytic and trachyandesitic compositions. Therefore, although local cumulatic structures are widespread, the selected samples are considered to represent approximate liquid compositions. The finegrained syenites, interpreted as more rapidly crystallized melts, are considered to represent the parental magma of fine-grained, alkali feldspar syenites and co-magmatic granites.

The variation of selected element contents using $\mathrm{SiO}_{2}$ as a differentiation index is illustrated in Figure 3. The mafic cumulates form a distinct group of low $\mathrm{SiO}_{2}$ values (below $50 \mathrm{wt} . \%$ ). They are interpreted as accumulations of early-crystallized diopside, augite, biotitephlogopite, and apatite. The relatively high contents of $\mathrm{Cr}$ and of the $\mathrm{Zr} / \mathrm{Hf}$ ratio confirm that pyroxene, instead of amphibole, was the original cumulus phase. High $\mathrm{K}_{2} \mathrm{O}, \mathrm{Rb}$, and $\mathrm{Cs}$ contents are due to the presence of mica, where partition coefficients for both trace elements are high. REE and Y contents in cumulates reflect the high amounts, up to 10 vol.\%, of apatite, as confirmed by the strong positive correlation of phosphorous and REE.

Whole-rock compositions were plotted in the $\mathrm{Ab}$ An-Or diagram. At pressures of $2 \mathrm{kbar}$ and $\mathrm{a}_{\mathrm{w}}=0.1$ (Fig. 4), the solvus curve separates the fine-grained syenites - which plot in the two-feldspar stability field - 
TABLE I

Major element data, X-ray fluorescence determinations - wt.\% - in the Piquiri Massif studied samples.

\begin{tabular}{|c|c|c|c|c|c|c|c|c|c|c|c|c|c|}
\hline Sample & Rock type & $\mathrm{SiO}_{2}$ & $\mathrm{Al}_{2} \mathrm{O}_{3}$ & $\mathrm{Fe}_{2} \mathrm{O}_{3} \mathrm{~T}$ & $\mathrm{MnO}$ & $\mathrm{MgO}$ & $\mathrm{CaO}$ & $\mathrm{Na}_{2} \mathrm{O}$ & $\mathrm{K}_{2} \mathrm{O}$ & $\mathrm{TiO}_{2}$ & $\mathrm{P}_{2} \mathrm{O}_{5}$ & LOI & Total \\
\hline 1 & bio pyrox. & 45.03 & 5.37 & 8.87 & 0.17 & 14.51 & 15.59 & 0.78 & 3.12 & 1.74 & 2.91 & 0.79 & 98.88 \\
\hline 2 & bio pyrox. & 45.26 & 6.79 & 9.28 & 0.16 & 13.04 & 13.91 & 0.80 & 4.44 & 1.98 & 2.89 & 0.82 & 99.37 \\
\hline 3 & bio pyrox. & 45.72 & 4.50 & 12.34 & 0.26 & 11.57 & 15.79 & 1.13 & 2.57 & 1.43 & 2.64 & 0.87 & 98.82 \\
\hline 4 & bio pyrox. & 46.63 & 7.94 & 7.07 & 0.13 & 10.19 & 14.48 & 1.11 & 4.88 & 0.94 & 3.95 & 0.99 & 98.31 \\
\hline 5 & bio pyrox. & 47.07 & 4.84 & 9.37 & 0.20 & 12.81 & 17.06 & 0.89 & 2.83 & 1.53 & 2.82 & 0.78 & 100.20 \\
\hline 6 & pyrox cum. & 55.60 & 8.34 & 10.63 & 0.20 & 5.66 & 8.28 & 2.96 & 4.17 & 1.20 & 1.14 & 0.90 & 99.08 \\
\hline 7 & fine grain. syen & 57.24 & 13.72 & 7.01 & 0.12 & 3.97 & 5.21 & 2.55 & 5.99 & 0.75 & 0.79 & 1.37 & 98.72 \\
\hline 8 & di ph perth syen & 57.37 & 13.12 & 6.20 & 0.12 & 4.16 & 5.65 & 2.66 & 7.49 & 0.88 & 0.83 & 0.76 & 99.24 \\
\hline 9 & di ph perth syen & 57.59 & 12.71 & 6.25 & 0.11 & 4.73 & 6.23 & 2.32 & 7.73 & 0.84 & 0.98 & 0.42 & 99.92 \\
\hline 10 & fine grain. syen & 57.81 & 16.39 & 6.00 & 0.11 & 2.86 & 5.24 & 4.56 & 5.36 & 0.61 & 0.50 & 0.52 & 99.96 \\
\hline 11 & fine grain. syen & 58.52 & 16.35 & 5.61 & 0.10 & 2.65 & 4.67 & 4.49 & 5.72 & 0.63 & 0.49 & 0.59 & 99.82 \\
\hline 12 & fine grain. syen & 59.43 & 12.76 & 6.06 & 0.10 & 3.80 & 4.90 & 2.92 & 7.52 & 0.79 & 0.81 & 0.71 & 99.80 \\
\hline 13 & fine grain. syen & 59.88 & 13.64 & 6.73 & 0.12 & 3.17 & 4.72 & 2.40 & 6.04 & 0.74 & 0.60 & 1.00 & 99.04 \\
\hline 14 & fine grain. syen & 59.97 & 13.71 & 6.49 & 0.12 & 3.28 & 4.96 & 2.33 & 6.49 & 0.73 & 0.71 & 1.15 & 99.94 \\
\hline 15 & di ph K-felds syen & 60.39 & 13.41 & 6.72 & 0.13 & 3.21 & 4.59 & 2.32 & 6.39 & 0.71 & 0.71 & 0.78 & 99.36 \\
\hline 16 & fine grain. syen & 61.52 & 13.90 & 6.28 & 0.11 & 2.92 & 4.02 & 2.57 & 5.63 & 0.76 & 0.63 & 1.41 & 99.75 \\
\hline 17 & K-felds syen & 61.60 & 13.61 & 5.46 & 0.09 & 2.41 & 3.61 & 3.67 & 6.78 & 0.63 & 0.62 & 0.46 & 98.94 \\
\hline 18 & K-felds syen & 62.35 & 15.88 & 4.62 & 0.10 & 1.95 & 2.74 & 3.79 & 6.54 & 0.67 & 0.39 & 0.80 & 99.83 \\
\hline 19 & K-felds syen & 63.53 & 14.58 & 4.67 & 0.07 & 1.98 & 2.71 & 3.85 & 7.67 & 0.49 & 0.38 & 0.80 & 100.73 \\
\hline 20 & Feldsp cum & 63.55 & 14.84 & 3.83 & 0.08 & 1.63 & 2.50 & 3.81 & 8.00 & 0.57 & 0.39 & 0.82 & 100.02 \\
\hline 21 & K-felds syen & 63.56 & 13.31 & 4.94 & 0.08 & 2.50 & 3.29 & 3.78 & 7.18 & 0.64 & 0.63 & 0.71 & 100.62 \\
\hline 22 & K-felds syen & 65.82 & 13.73 & 3.76 & 0.06 & 1.76 & 2.18 & 3.67 & 6.87 & 0.46 & 0.44 & 0.54 & 99.29 \\
\hline 23 & qz K-felds syen & 65.99 & 12.62 & 4.28 & 0.06 & 2.44 & 2.79 & 3.04 & 6.28 & 0.46 & 0.54 & 0.84 & 99.34 \\
\hline 24 & K-felds gran & 70.92 & 13.91 & 2.24 & 0.02 & 0.73 & 0.74 & 3.31 & 7.50 & 0.32 & 0.05 & 0.42 & 100.16 \\
\hline 25 & K-felds gran & 77.04 & 12.08 & 1.40 & 0.01 & 0.08 & 0.12 & 3.08 & 6.36 & 0.16 & 0.03 & 0.53 & 100.89 \\
\hline 26 & K-felds gran & 73.68 & 13.02 & 1.07 & 0.01 & 0.17 & 0.41 & 2.79 & 7.21 & 0.11 & 0.04 & 0.38 & 98.88 \\
\hline 27 & K-felds gran & 74.23 & 12.82 & 1.27 & 0.02 & 0.27 & 0.85 & 3.07 & 6.54 & 0.10 & 0.17 & 0.34 & 99.68 \\
\hline 28 & K-felds gran & 74.68 & 13.57 & 0.45 & 0.00 & 0.07 & 0.23 & 2.74 & 8.07 & 0.08 & 0.03 & 0.37 & 100.29 \\
\hline 29 & Syenogranite & 75.55 & 12.76 & 0.57 & 0.01 & 0.06 & 0.68 & 4.92 & 3.26 & 0.10 & 0.02 & 0.25 & 98.18 \\
\hline 30 & Syenogranite & 75.71 & 12.70 & 1.31 & 0.01 & 0.32 & 0.39 & 3.74 & 5.71 & 0.17 & 0.10 & 0.50 & 100.66 \\
\hline 31 & Syenogranite & 73.40 & 14.46 & 0.98 & 0.01 & 0.11 & 0.54 & 4.48 & 5.47 & 0.06 & 0.02 & 0.39 & 99.92 \\
\hline
\end{tabular}

from both types of alkali feldspar syenites. The finegrained syenites plot close to the experimentally determined field (Nekvasil 1990) where partial resorption of plagioclase would be expected. The textural and mineralogical evolution of the syenitic rocks in the Piquiri Massif is compatible with that described for trachytic experimental melts performed by Nekvasil (1990), and this is taken as additional evidence that the rocks represent melt compositions.

\section{Chemical Classification and AfFinity}

CIPW norm calculations show that most rocks in the Piquiri Massif are $\mathrm{SiO}_{2}$ saturated, and the presence of under-saturated compositions is only common in cumulates, where normative nepheline may reach up to 4 wt.\%. Normative-quartz contents increase in the more differentiated syenites and alkali feldspar syenites, but among the less differentiated terms normative-olivine 
TABLE II

Trace element data, ICP-MS determinations - ppm - for the Piquiri Syenite Massif studied samples.

\begin{tabular}{|c|c|c|c|c|c|c|c|c|c|c|c|c|c|c|c|c|}
\hline Sample & $\mathrm{Ba}$ & $\mathrm{Rb}$ & $\mathrm{Sr}$ & Cs & $\mathrm{Ga}$ & $\mathrm{Ta}$ & $\mathrm{Nb}$ & $\mathrm{Hf}$ & $\mathrm{Zr}$ & $\mathrm{Y}$ & $\mathrm{Th}$ & $\mathrm{U}$ & $\mathrm{Cr}$ & $\mathrm{Ni}$ & $\mathrm{Co}$ & V \\
\hline 1 & 2340 & 235 & 1500 & 13 & 13 & 1.0 & 22 & 2 & 71 & 40 & 19 & 3 & 362 & 61 & 48 & 164 \\
\hline 2 & 4463 & 227 & 1446 & 12 & & 1.0 & 15 & 3 & 48 & 42 & 11 & 3 & 222 & 46 & 54 & 172 \\
\hline 3 & 1408 & 220 & 1125 & 17 & & 1.0 & 14 & 5 & 127 & 57 & 16 & 2 & 214 & 50 & 61 & 228 \\
\hline 4 & 5446 & 310 & 2149 & 19 & & 1.0 & 27 & 10 & 288 & 38 & 48 & 11 & 282 & 44 & 37 & 99 \\
\hline 5 & 2689 & 187 & 1622 & 12 & & 1.0 & 15 & 5 & 98 & 39 & 18 & 2 & 240 & 51 & 57 & 165 \\
\hline 6 & 1731 & 158 & 1244 & 2 & 18 & 6.0 & 63 & 35 & 143 & 53 & 70 & 15 & 121 & 53 & 58 & 149 \\
\hline 7 & 3820 & 223 & 1285 & 6 & 19 & 1.0 & 11 & 5 & 195 & 26 & 14 & 3 & 52 & 21 & 54 & 129 \\
\hline 8 & 4350 & 364 & 1510 & 19 & 19 & 1.0 & 18 & 4 & 129 & 23 & 9 & 5 & 53 & 10 & 20 & 129 \\
\hline 9 & 4278 & 260 & 1539 & 10 & & 1.0 & 15 & 5 & 236 & 23 & 13 & 3 & 81 & 16 & 21 & 117 \\
\hline 10 & 2620 & 172 & 1260 & 9 & 20 & 2.0 & 25 & 7 & 253 & 18 & 24 & 6 & 10 & 10 & 15 & 85 \\
\hline 11 & 2620 & 176 & 1520 & 8 & 19 & 2.0 & 24 & 7 & 256 & 17 & 27 & 19 & 10 & 10 & 14 & 78 \\
\hline 12 & 4231 & 335 & 1550 & 15 & 23 & 3.0 & 61 & 9 & 378 & 24 & 48 & 7 & 91 & 33 & 18 & 95 \\
\hline 13 & 3548 & 246 & 1090 & 6 & 22 & 1.0 & 28 & 6 & 235 & 32 & 20 & 5 & 82 & 29 & 18 & 119 \\
\hline 14 & 3237 & 268 & 1030 & 5 & 19 & 1.0 & 14 & 6 & 216 & 29 & 22 & 5 & 38 & 15 & 48 & 115 \\
\hline 15 & 3349 & 279 & 990 & 7 & 21 & 1.0 & 28 & 6 & 239 & 29 & 21 & 5 & 51 & 43 & 18 & 124 \\
\hline 16 & 2888 & 226 & 969 & 6 & 19 & 1.0 & 15 & 7 & 250 & 27 & 21 & 5 & 42 & 32 & 72 & 100 \\
\hline 17 & 3400 & 282 & 1560 & 10 & 23 & 3.0 & 51 & 41 & 167 & 22 & 80 & 21 & 159 & 89 & 17 & 74 \\
\hline 18 & 2218 & 198 & 1496 & & & & 57 & & 781 & & & & & 17 & 21 & 93 \\
\hline 19 & 3243 & 244 & 1507 & & & & 44 & & 891 & & & & & 53 & 18 & 72 \\
\hline 20 & 3946 & 285 & 1759 & 4 & 22 & 3.0 & 33 & 14 & 575 & 19 & 56 & 10 & 49 & 61 & 46 & 57 \\
\hline 21 & 3069 & 340 & 1277 & 10 & 21 & 4.0 & 42 & 12 & 418 & 20 & 73 & 20 & 40 & 14 & 52 & 61 \\
\hline 22 & 2878 & 268 & 991 & 5 & 19 & 2.0 & 31 & 12 & 464 & 19 & 51 & 7 & 45 & 22 & 74 & 43 \\
\hline 23 & 2775 & 227 & 1227 & 5 & 19 & 2.0 & 20 & 9 & 322 & 17 & 21 & 5 & 55 & 66 & 60 & 55 \\
\hline 24 & 2954 & 325 & 947 & 9 & & 2.0 & 32 & 9 & 203 & 4 & 43 & 24 & 13 & 1 & 5 & 46 \\
\hline 25 & 1147 & 303 & 364 & 9 & 22 & 9.0 & 79 & 11 & 248 & 11 & 138 & 31 & 5 & 5 & 121 & 9 \\
\hline 26 & 2660 & 283 & 994 & 6 & 14 & 2.0 & 10 & 8 & 238 & 5 & 181 & 39 & 10 & 10 & 1 & 15 \\
\hline 27 & 1530 & 231 & 691 & 7 & 14 & 2.0 & 19 & 3 & 63 & 12 & 18 & 16 & 10 & 10 & 2 & 9 \\
\hline 28 & 2022 & 305 & 933 & 6 & & 1.0 & 9 & 2 & 72 & 3 & 14 & 7 & 2 & 1 & 1 & 11 \\
\hline 29 & 497 & 209 & 404 & 10 & 23 & 6.0 & 36 & 6 & 122 & 12 & 64 & 28 & 10 & 29 & 1 & 3 \\
\hline 30 & 1616 & 300 & 646 & 23 & 24 & 13. & 31 & 8 & 464 & 19 & 60 & 32 & 15 & 5 & 98 & 16 \\
\hline 31 & 1830 & 259 & 955 & 7 & 23 & 3.0 & 14 & 4 & 63 & 4 & 27 & 13 & 10 & 10 & 1 & 15 \\
\hline
\end{tabular}

contents of up to $14 \mathrm{wt} . \%$ may be found, particularly in cumulates. Significant contents of normative corundum or acmite were not observed in the studied samples, and their ACNK values characterize most of them as metaluminous. Norm calculations indicate that the studied syenitic rocks are metaluminous and belong to the silicasaturated magmatic series.

In the R1-R2 diagram (De La Roche 1980) finegrained syenites plot in the field of monzonites, alkali feldspar syenites spread in the fields of syenites, quartzsyenites and quartz-monzonites, and the phlogopite- bearing alkali feldspar syenites plot in the syenodiorite field. The fine-grained and phlogopite-bearing syenites plot in the fields of syenodiorites and monzonites mainly because of their relatively high amounts of diopside, which cause an increase of R2 parameter due to $\mathrm{Ca}$ abundance.

Rocks with less than 50 wt. $\% \mathrm{SiO}_{2}$ (Fig. 5) are hornblende-biotite pyroxenites and correspond to samples interpreted as cumulates based on field and textural evidences. Most syenitic samples have $\mathrm{SiO}_{2}$ contents in the range of 54 to $66 \mathrm{wt} . \%$ and correspond to magmatic 
TABLE II (continuation)

\begin{tabular}{|c|c|c|c|c|c|c|c|c|c|c|c|c|c|c|c|c|}
\hline Sample & $\mathrm{Pb}$ & $\mathrm{Zn}$ & $\mathrm{La}$ & $\mathrm{Ce}$ & $\operatorname{Pr}$ & $\mathrm{Nd}$ & $\mathrm{Sm}$ & $\mathrm{Eu}$ & $\mathrm{Gd}$ & $\mathrm{Tb}$ & Dy & Ho & Er & $\mathrm{Tm}$ & $\mathrm{Tb}$ & $\mathrm{Lu}$ \\
\hline 1 & 6 & 76 & 173 & 322 & 37.8 & 147 & 25.5 & 6.07 & 17.9 & 2.20 & 9.20 & 1.40 & 3.50 & 0.42 & 2.80 & 0.39 \\
\hline 2 & 8 & 84 & 208 & 384 & & 170 & 30.5 & 7.70 & & 2.50 & & & & & 2.30 & 0.35 \\
\hline 3 & 6 & 124 & 319 & 555 & & 243 & 38.9 & 9.10 & & 2.80 & & & & & 4.50 & 0.70 \\
\hline 4 & 4 & 99 & 280 & 512 & & 204 & 35.5 & 9.70 & & 0.25 & & & & & 2.10 & 0.31 \\
\hline 5 & 11 & 75 & 216 & 395 & & 195 & 29.5 & 7.60 & & 1.60 & & & & & 2.80 & 0.43 \\
\hline 6 & 25 & 128 & 232 & 406 & 44.9 & 167 & 29.7 & 6.81 & 19.3 & 2.52 & 10.0 & 1.70 & 4.23 & 0.54 & 3.21 & 0.47 \\
\hline 7 & 64 & 81 & 76 & 147 & 16.3 & 67 & 12.4 & 2.90 & 8.39 & 1.11 & 5.09 & 0.84 & 2.39 & 0.30 & 1.80 & 0.26 \\
\hline 8 & 30 & 69 & 79 & 149 & 16.9 & 64 & 11.7 & 2.65 & 7.80 & 1.10 & 4.80 & 0.80 & 2.10 & 0.28 & 1.70 & 0.25 \\
\hline 9 & 29 & 72 & 104 & 178 & & 65 & 12.6 & 3.20 & & 0.25 & & & & & 1.60 & 0.25 \\
\hline 10 & 70 & 89 & 75 & 136 & 15.1 & 54 & 8.90 & 2.42 & 6.80 & 0.80 & 3.90 & 0.70 & 2.00 & 0.26 & 1.60 & 0.24 \\
\hline 11 & 42 & 69 & 74 & 135 & 14.6 & 52 & 8.60 & 2.49 & 6.40 & 0.80 & 3.70 & 0.70 & 1.90 & 0.25 & 1.60 & 0.23 \\
\hline 12 & 63 & 68 & 115 & 164 & 19.7 & 89 & 14.3 & 3.20 & 10.9 & 1.28 & 5.25 & 0.76 & 2.37 & 0.29 & 1.57 & 0.24 \\
\hline 13 & 41 & 63 & 99 & 107 & 14.2 & 66 & 12.2 & 2.82 & 9.11 & 1.25 & 5.93 & 0.97 & 2.82 & 0.39 & 2.40 & 0.34 \\
\hline 14 & 52 & 79 & 70 & 134 & 15.5 & 61 & 11.8 & 2.75 & 8.39 & 1.21 & 5.62 & 0.94 & 2.79 & 0.38 & 2.18 & 0.34 \\
\hline 15 & 67 & 96 & 86 & 103 & 14.4 & 64 & 11.2 & 2.55 & 9.40 & 1.25 & 5.48 & 0.93 & 3.00 & 0.41 & 2.11 & 0.33 \\
\hline 16 & 58 & 83 & 69 & 136 & 14.8 & 60 & 11.1 & 2.56 & 8.12 & 1.13 & 5.45 & 0.96 & 2.71 & 0.38 & 2.30 & 0.33 \\
\hline 17 & 53 & 103 & 145 & 241 & 24.8 & 85 & 12.7 & 3.34 & 8.90 & 1.00 & 4.70 & 0.80 & 2.30 & 0.32 & 2.20 & 0.33 \\
\hline 18 & 41 & 65 & & & & & & & & & & & & & & \\
\hline 19 & 38 & 101 & & & & & & & & & & & & & & \\
\hline 20 & 29 & 55 & 103 & 191 & 19.1 & 67.8 & 11.4 & 2.90 & 6.89 & 0.93 & 3.98 & 0.62 & 1.62 & 0.20 & 1.19 & 0.18 \\
\hline 21 & 56 & 87 & 101 & 185 & 19.4 & 70.6 & 12.3 & 2.95 & 7.63 & 1.02 & 4.22 & 0.67 & 1.87 & 0.25 & 1.53 & 0.23 \\
\hline 22 & 35 & 60 & 99 & 193 & 18.1 & 64.7 & 10.7 & 2.62 & 7.01 & 0.89 & 3.70 & 0.61 & 1.64 & 0.21 & 1.28 & 0.20 \\
\hline 23 & 39 & 64 & 89 & 161 & 16.1 & 60.1 & 9.64 & 2.45 & 6.40 & 0.81 & 3.68 & 0.59 & 1.74 & 0.23 & 1.35 & 0.21 \\
\hline 24 & 29 & 31 & 23 & 43 & & 16.0 & 2.20 & 1.00 & & 0.25 & & & & & 0.70 & 0.11 \\
\hline 25 & 45 & 5 & 45 & 94 & 7.83 & 23.5 & 4.06 & 0.99 & 2.41 & 0.41 & 2.07 & 0.36 & 1.14 & 0.19 & 1.23 & 0.17 \\
\hline 26 & 22 & 15 & 13.6 & 25 & 2.91 & 10.5 & 1.80 & 0.57 & 1.20 & 0.20 & 0.90 & 0.20 & 0.40 & 0.07 & 0.50 & 0.08 \\
\hline 27 & 34 & 15 & 15.4 & 25 & 2.61 & 9.00 & 1.90 & 0.75 & 1.80 & 0.40 & 2.20 & 0.40 & 1.30 & 0.19 & 1.10 & 0.17 \\
\hline 28 & 24 & 16 & 9.7 & 19 & & 9.00 & 1.60 & 0.60 & & 0.25 & & & & & 0.50 & 0.08 \\
\hline 29 & 29 & 15 & 56 & 87 & 6.46 & 18.2 & 2.70 & 0.38 & 1.70 & 0.40 & 2.10 & 0.40 & 1.20 & 0.20 & 1.20 & 0.17 \\
\hline 30 & 95 & 29 & 22.9 & 33 & 5.02 & 19.3 & 3.61 & 0.92 & 2.47 & 0.35 & 1.75 & 0.30 & 0.97 & 0.16 & 1.06 & 0.17 \\
\hline 31 & 37 & 15 & 3.1 & 5.8 & 0.74 & 3.10 & 0.80 & 0.30 & 0.70 & 0.10 & 0.80 & 0.10 & 0.40 & 0.06 & 0.40 & 0.06 \\
\hline
\end{tabular}

liquids of trachytic and trachyandesitic or latitic compositions (Le Maitre 2002). Fine- to medium-grained syenites are slightly $\mathrm{SiO}_{2}$-enriched and poorer in alkali elements when compared to the coarser grained alkali feldspar syenites (Fig. 5). The phlogopite-bearing alkali feldspar syenites plot very close to the lamprophyric enclaves in the TAS diagram. Both hypersolvus and subsolvus granites correspond to rhyolitic compositions in the TAS diagram. The least differentiated syenitic rocks of Piquiri Massif plot as trachyandesites in the field of silica-saturated alkaline series and could be classified as shoshonitic or potassic, as referred by Le Maitre (2002), since their $\mathrm{K}_{2} \mathrm{O}$ contents are higher than $\left(\mathrm{Na}_{2} \mathrm{O}-2\right)$. However, the $\mathrm{K}_{2} \mathrm{O} / \mathrm{Na}_{2} \mathrm{O}$ ratios of Piquiri Massif syenitic rocks are higher than 2, which are not usual in shoshonitic rocks, as discussed by Plá Cid et al. (2000). Therefore, following the suggestion of these authors, the Piquiri Massif syenitic rocks are considered ultrapotassic, and not shoshonitic. The trend defined in the FMA diagram (Brown 1981) (Fig. 6a) is similar to that observed in non-tholeiitic liquids. In the Mn-Ti-P diagram (Mullen 1983) (Fig. 6b) most of the samples plot in the field of ocean island andesites. Diagrams based on trace elements such as $\mathrm{Zr} / \mathrm{Ti}$ versus $\mathrm{Nb} / \mathrm{Y}$ (Fig. 6c) (Winch- 


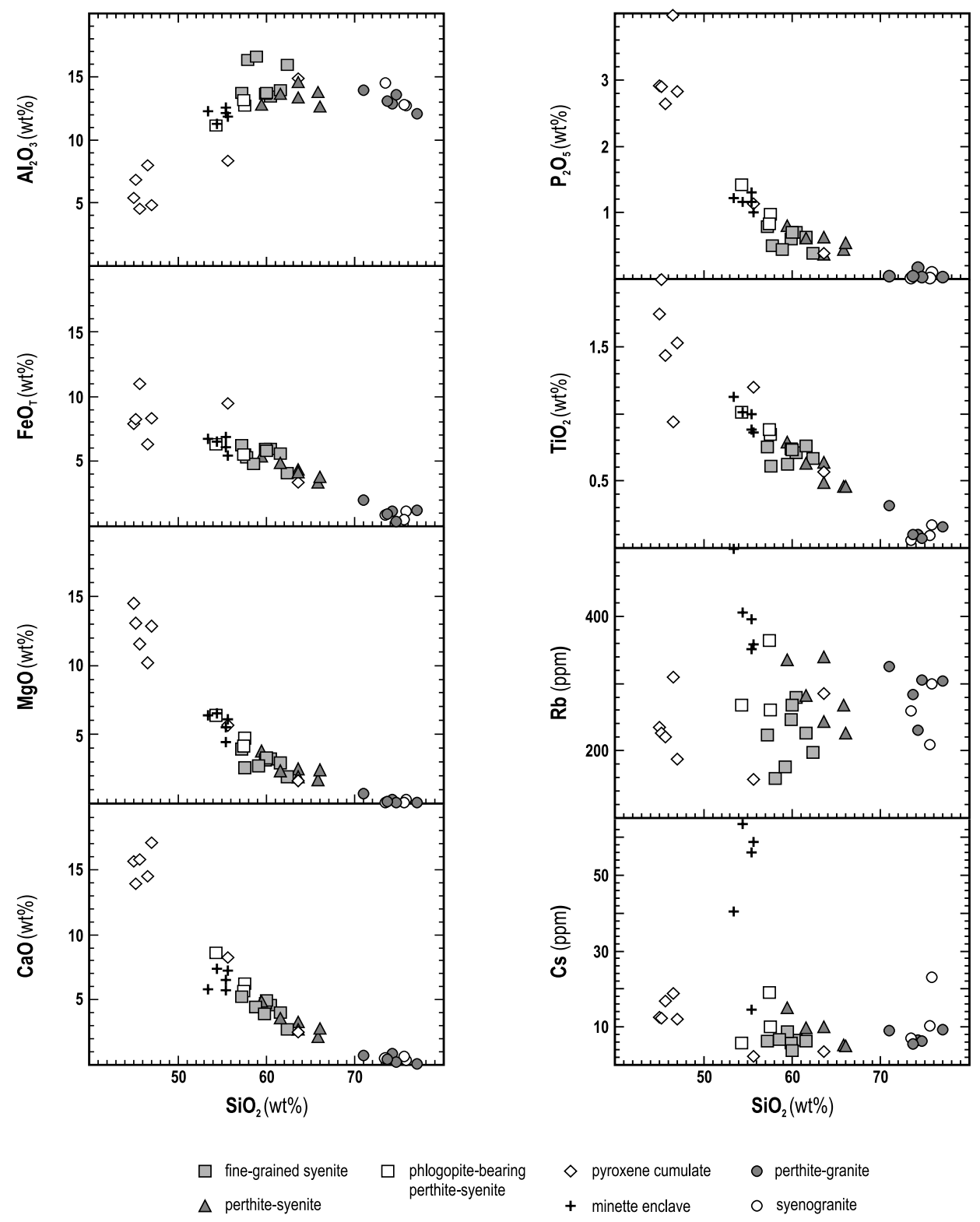

Fig. 3 - Harker diagrams for some major and trace elements in Piquiri Syenite Massif samples.

ester and Floyd 1977) confirm the compositional similarity of fine-grained syenites with trachyandesites, as well as the mildly alkaline character of this magmatism. REE chondrite-normalized patterns (Fig. 7) show high LREE to HREE ratio $\left(\mathrm{Ce}_{\mathrm{N}} / \mathrm{Yb}_{\mathrm{N}} 30-50\right)$ and sharp LREE enrichment, with $\mathrm{Ce}_{\mathrm{N}}$ values about 400-600. Similar patterns have been described, for example, in ultrapotassic syenites of Archaean age from Quebéc (Laflèche et al. 1991), lamproitic ultrapotassic rocks from the Aeolian arc (De
Astis et al. 2000), and in ultrapotassic syenites from Santanápolis Massif, northeastern Brazil (Conceição et al. 2000b). Eu does not show significant anomalies in the syenitic rocks, which confirms that they are not feldspar cumulates. Mafic cumulates are REE-enriched because of the relatively high amounts of apatite, whilst the late granitic differentiates show the most depleted patterns $\mathrm{Ce}_{\mathrm{N}}$ around 100 - with small, negative and positive $\mathrm{Eu}$ anomalies due to magmatic flow segregation of feldspars. 


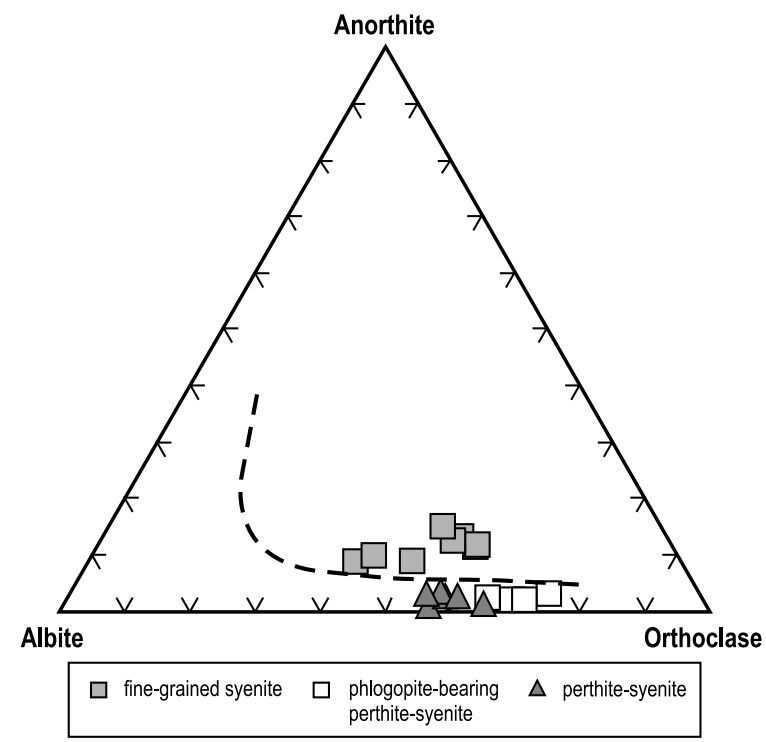

Fig. 4 - Syenitic rocks plotted in the Ab-An-Or normative diagram. Dashed curve from Nekvasil (1990) for quartz-saturated systems at 2 kbar and $\mathrm{a}_{\mathrm{w}}=0.1$.

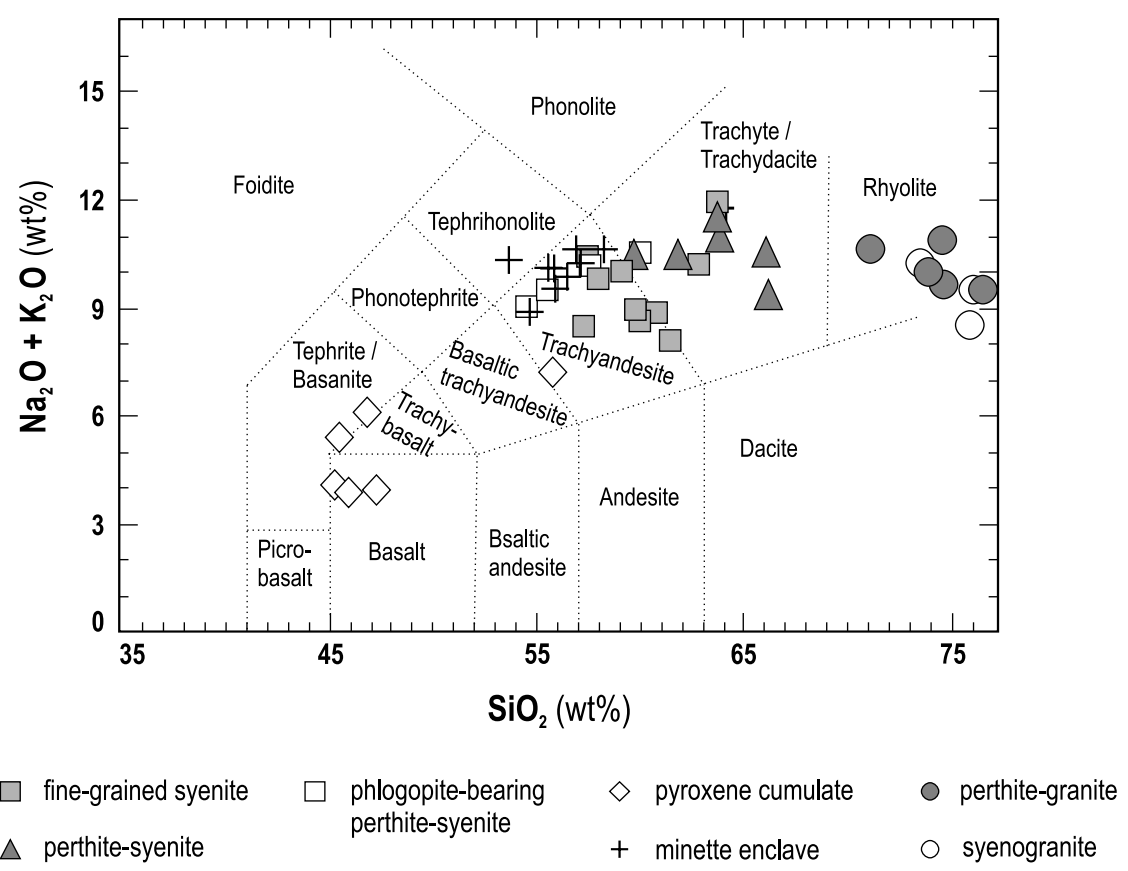

Fig. 5 - Samples from Piquiri Syenite Massif in the TAS diagram, plotting in the field of alkaline silica-saturated series.

The granite rocks from Piquiri Syenite Massif share some important features with A-type granites such as the high alkali contents and the genetic relationship with alkaline rocks, and so can be considered as A-type rocks.

The lamprophyric mafic microgranular enclaves were described from a geochemical point-of-view by Nardi et al. (2007) and were described as slightly silicaundersaturated, ultrapotassic and metaluminous, with $\mathrm{K}_{2} \mathrm{O} / \mathrm{Na}_{2} \mathrm{O}$ ratios around 2-3, and with about $4-7$ wt.\% of $\mathrm{K}_{2} \mathrm{O}$. 


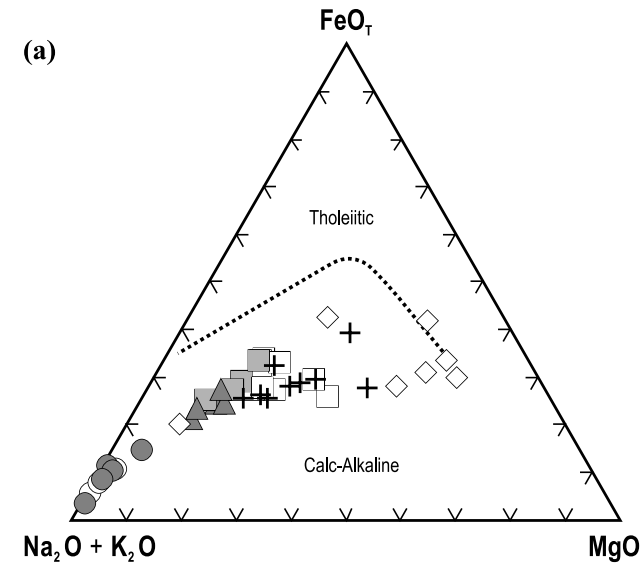

(a)$$
\mathrm{Na}_{2} \mathrm{O}+\mathrm{K}_{2} \mathrm{O}
$$

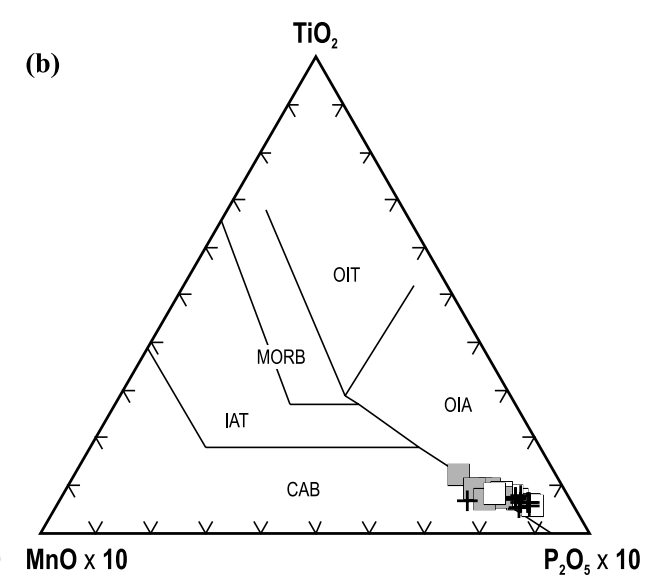

(c)

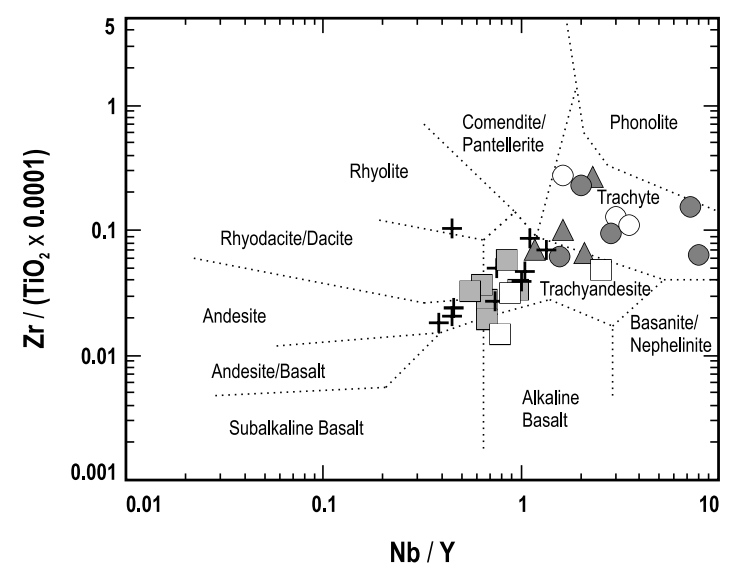

Fig. 6 - Major and trace element plots: (a) in the AFM diagram the samples plot in the non-tholeiitic field; (b) most samples plot in the fields of ocean island arcs (OIA) and continental arc basalts (CAB); OIT - ocean island tholeiites, MORB - mid-ocean ridge basalts, IAT - island arc tholeiites; (c) the samples plot mostly in the fields of alkaline rocks - trachyandesites and trachytes.

\section{MAGMATIC SOURCES AND SETTINGS}

$\mathrm{K}_{2} \mathrm{O}$ and $\mathrm{TiO}_{2}$ contents, as well as $\mathrm{Th} / \mathrm{U}$ and $\mathrm{Rb} / \mathrm{Sr}$ ratios, are similar to those of the potassic magmatism in the Italian Province, where Rogers (1992) took these geochemical features as indicative of sources affected by subduction, including a sedimentary component. The same influence of lithospheric subduction on the mantle source is indicated by $\mathrm{Zr}$ versus $\mathrm{Nb}$ contents (Leat et al. 1986) and by the relationship of $\mathrm{MgO}-\mathrm{FeOT}-\mathrm{Al}_{2} \mathrm{O}_{3}$, illustrated in the diagram suggested by Pearce et al. (1977, Fig. 8a). The $\mathrm{Nb}$ contents, generally varying from 10 to $35 \mathrm{ppm}$ in the Piquiri Massif samples, are also consistent with magmatic sources affected by lithospheric subduc- tion. Higher values are observed in rocks with probable accretion of amphibole and mica by magmatic flow mineral segregation, both effective Nb-carriers (Plá Cid et al. 2005).

The similarity of the studied syenitic compositions with those of basaltic differentiates generated at destructive plate margins is suggested by the Th-Ta-Hf diagram (Wood 1980) (Fig. 8b).

Spidergrams were constructed comparing the less differentiated Piquiri syenitic rocks. Compared with MORB, E-MORB, N-MORB, and OIB patterns, the mantle-incompatible element trends found in the Piquiri Massif rocks are best approximated by the ocean island basalts - OIB patterns (Fig. 9). The fine-grained syen- 

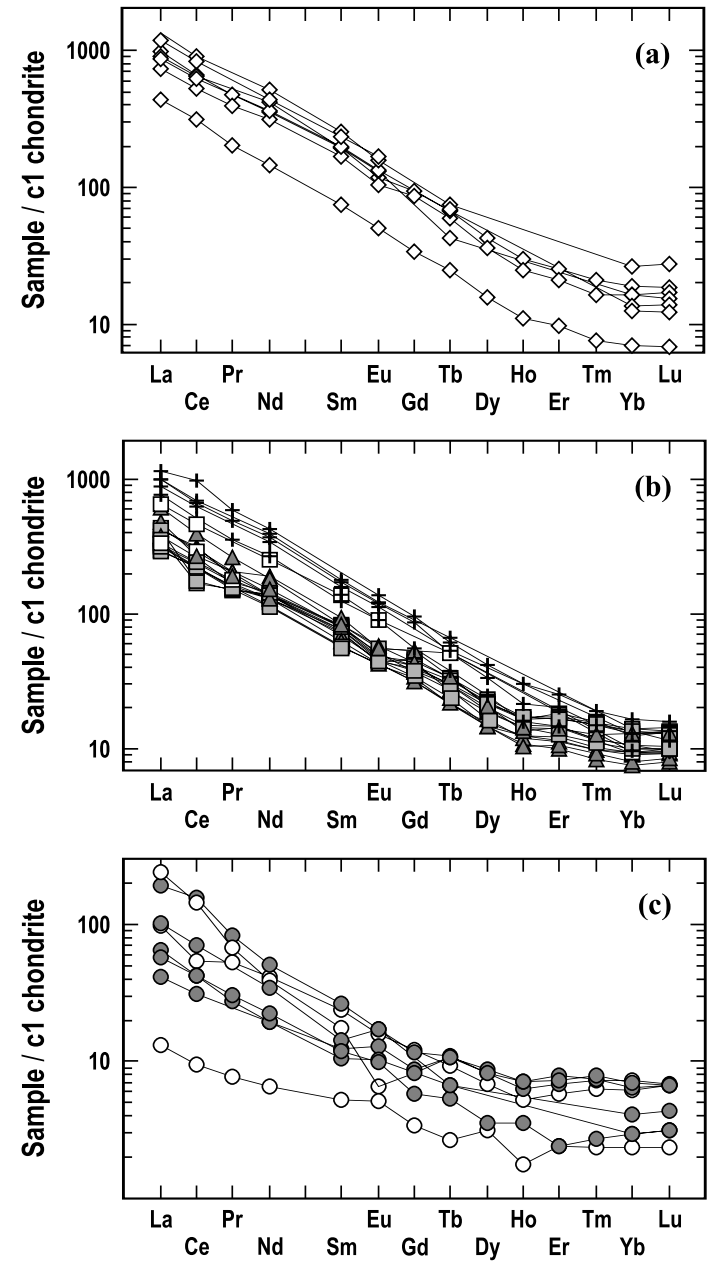

Fig. 7 - REE patterns, normalized against $\mathrm{C} 1$ chondrite (Evensen et al. 1978), for Piquiri Syenite Massif samples: (a) apatite-bearing pyroxene cumulates, (b) lamprophyric mafic microgranular enclaves and syenitic rocks; (c) ultrapotassic granites. Symbols as in Figure 6.

ites, presumably representative of the Piquiri parental magmas, show HRE- and HFS-element patterns similar to those of OIB, with slight LREE and Sr enrichment and much higher concentrations of LILE, Th and U, elements of high incompatibility in the mantle. The spidergrams also illustrate the deep anomalies of $\mathrm{Nb}$ and $\mathrm{Ta}$ in relation to LREE, which have been interpreted as typical of magmas produced from sources affected by lithospheric subduction or delamination (Kay and MahlburgKay 1991).

According to Pearce (1982), subduction-related melts compared to OIB or MORB's show different relationships between K, Ta, and $\mathrm{Yb}$. Rogers (1992) used
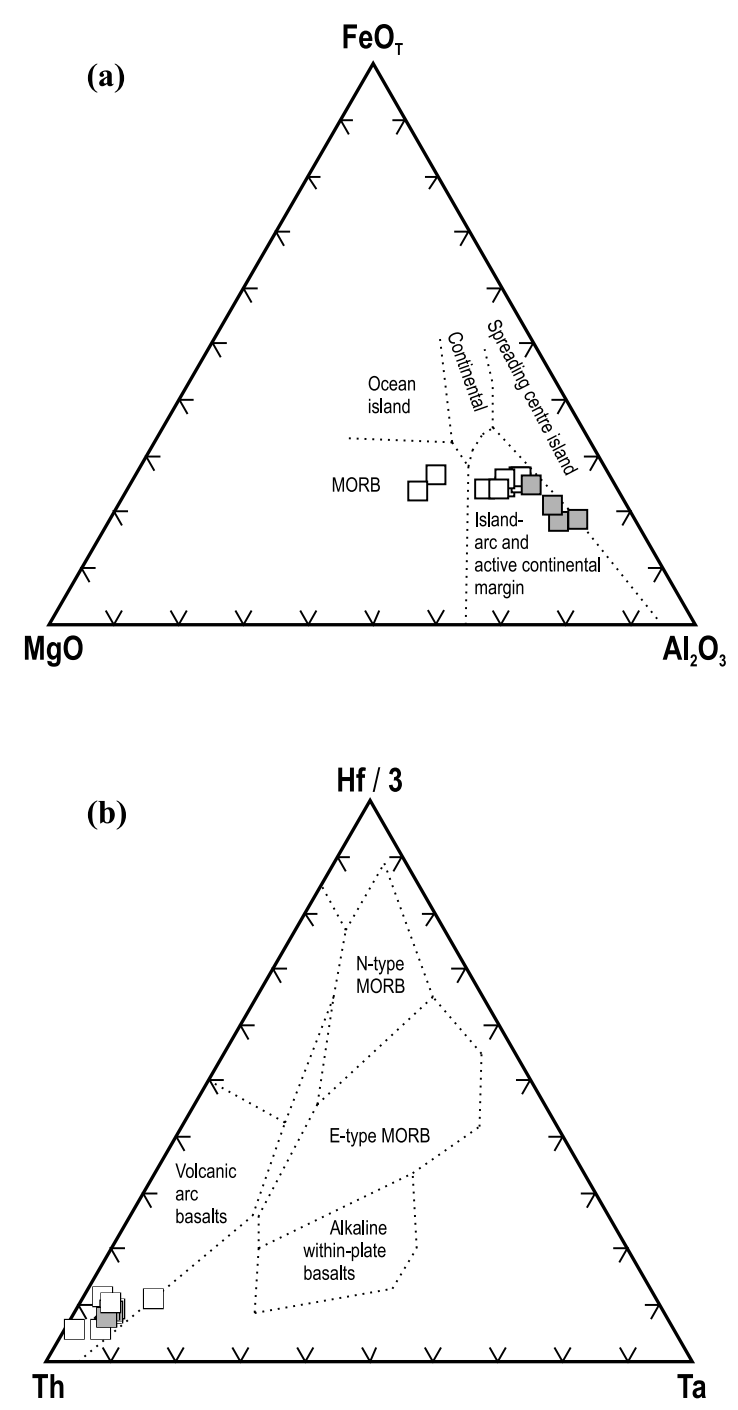

Fig. 8 - Major and trace element plots for geotectonic interpretations. (a) Fields after Pearce et al. (1977): 1 - spreading centre island, 2 island arc and active continental margin, 3 - mid-ocean ridge, 4 - ocean island, 5 - continental. Most syenitic samples plot in the field of volcanic rocks from island arcs and active continental margins. (b) Fields after Wood (1980): A - N-type MORB, B - E-type MORB, C - alkaline within-plate basalts, $\mathrm{D}$ - volcanic arc basalts;. The studied samples plot in the field of calc-alkaline volcanic arc basalts, with $\mathrm{Th} / \mathrm{Hf}<3$. Symbols as in Figure 6.

the $\mathrm{K} / \mathrm{Yb}$ versus $\mathrm{Ta} / \mathrm{Yb}$ diagram for characterizing the source of potassic rocks from the Italian Province as related to subduction. The Piquiri Massif rocks plot in the same field as leucititic high-potassium orogenic volcanic rocks described by that author. Such geochemi- 


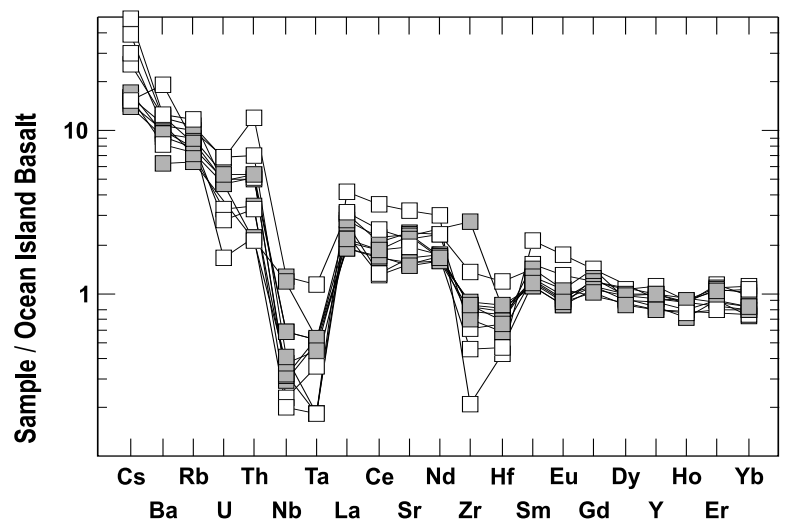

Fig. 9 - Spidergram for trace elements in the Piquiri Syenite Massif syenites normalized against the OIB values of Sun (1980). Symbols as in Figure 6.

cal trends are comparable to those of magmatic rocks derived from phlogopite-apatite-amphibole-bearing heterogeneous and enriched mantle, which results from previous metasomatism related to lithospheric subduction (Foley 1992, Carmichael et al. 1996).

\section{PETROGENESIS OF SYENITIC AND GRANITIC ROCKS}

Assuming that the Piquiri syenitic rocks, in spite of their abundant cumulate structures, dominantly represent crystallized melts, their probable parental magma would be approximately represented by the faster-crystallized and less differentiated, fine- to medium-grained syenites. Such trachytic or syenitic magma, as assumed by most authors (e.g. Thompson and Fowler 1986), could either be derived from lamprophyric magmas by fractional crystallization or represent a primary magma of intermediate composition, as suggested by Conceição and Green (2004). Melzer and Foley (2000) have demonstrated the possibility of generating quartz-bearing rocks from $\mathrm{SiO}_{2}$ saturated or undersaturated mafic or ultramafic magmas when phlogopite is one of the fractionated phases.

Nardi et al. (2007), comparing the compositions of lamprophyric MME and the fine-grained syenitic rocks of the Piquiri Massif, concluded that the higher contents of $\mathrm{Cs}, \mathrm{Rb}$, LREE, $\mathrm{U}$, and $\mathrm{Sr}$ in the enclaves, and the different $\mathrm{Zr} / \mathrm{Hf}, \mathrm{Nb} / \mathrm{Ta}$, and $\mathrm{TH} / \mathrm{U}$ ratios in both magmas, are not consistent with the evolution of co-magmatic liquids. They concluded that both magmas were produced from similar sources, a veined phlogopite-apatite- clinopyroxene-bearing mantle, and that the observed compositional differences probably reflect slight variations in the source mineralogy or in the fraction of extracted melt. As discussed by Foley (1992), a heterogeneous, veined mantle, with abundant phlogopite and apatite, is the most probable source of such incompatible-element enriched melts. Metasomatism related to a Brasiliano/Pan-African subduction (ca. 700-760 Ma) would have caused the "orogenic" trace element signature of syenitic parental magmas and promoted, as well, the abundance of volatile-bearing phases in the mantle source.

The fine-grained syenites represent the parental magma of most Piquiri rocks, and their relatively rapid crystallization has led to the preservation of near-liquidus phases, such as plagioclase. The dominant alkali feldspar syenites result from slower crystallization of more evolved liquids, with lesser amounts of mafic phases, where mineral segregation, cumulate structures and mafic microgranular enclaves, are widespread. Hypersolvus crystallization is caused by the lower amounts of An-component. Both, syenites and granites, have major and trace element patterns indicative of their comagmatic character, and may be explained as products of fractional crystallization (Plá Cid and Nardi 2006). Compositional variation is increased by mineral segregation and cumulative features, as discussed from petrographic and field evidences.

The phlogopite-bearing alkali feldspar syenites can be interpreted as a different magmatic pulse. They are mineralogical and compositionally so similar to lamprophyric enclaves that one must consider the possibility that they represent the lamprophyric magma mixed in variable proportions with the syenitic one, and crystallized under plutonic conditions, as discussed by Nardi et al. (2007).

The alkali feldspar granites and syenogranites from the Piquiri Massif are interpreted in accordance to the following statement (Nekvasil 1992, p.601): "Trachytes crystallizing under $\mathrm{H}_{2} \mathrm{O}$-buffered conditions could readily produce only high-temperature granites during late stage crystallization. Differentiation of high $\mathrm{T}$ syenitic magmas, as long as the syenitic magma crystallizes under $\mathrm{H}_{2} \mathrm{O}$-unbuffered conditions, can produce low $\mathrm{T}$ wet granites". The estimation of zircon crystallization tem- 
peratures based on zircon solubility (Watson and Harrison 1983) indicates about $730^{\circ} \mathrm{C}$ for the syenogranites and $820^{\circ} \mathrm{C}$ for the alkali feldspar granites, which are consistent with such interpretation and with the hypersolvus and subsolvus character of both granites.

Mass balance calculations for major elements were done with the program GENESIS developed by Leo Fernandes, based on a modification of XLFRAC (Stormer and Nicholls 1978). According to this, fractionation of about 70-90 wt.\% of an assemblage with alkali feldspar $(36$ wt.\%) + diopside $(23$ wt. $\%)+$ mica $(23$ wt. $\%)+$ andesine $(15 \mathrm{wt} . \%)+$ apatite (3 wt. $\%)$ could have generated granitic compositions similar to those of the Piquiri granites considering an initial composition equivalent to the fine-grained syenites. The slight variations in granite REE patterns, particularly for $\mathrm{Eu}$, are ascribed to mineral segregation controlled by magmatic flow. Negative $\mathrm{Eu}$ anomalies are not produced by feldspar fractionation due to the effect of apatite, which concentrates much less divalent Eu than the trivalent REE. The bulk distribution coefficient of Eu and their trivalent neighbors in the fractionated assemblage is close to 2 .

Based on field relations and on the consistency of petrographic, mineralogical and geochemical data, the co-magmatic character of granites and syenitic rocks, as well as their origin by fractional crystallization, are assumed. This granite type can not be considered as shoshonitic, since it is co-magmatic with ultrapotassic syenites and has higher $\mathrm{K}_{2} \mathrm{O} / \mathrm{Na}_{2} \mathrm{O}$ ratios and alkali contents than typical shoshonitic granites. The Piquiri syenogranites and alkali feldspar granites are, therefore, ultrapotassic granites, and could be considered as another sub-group of A-type or, more properly, as granites belonging to the silica-saturated ultrapotassic series, as suggested by Plá Cid and Nardi (2006). The same type of granite has been described elsewhere by Bourne and L'Heureux (1991) and Plá Cid et al. (2000) among other authors.

\section{FINAL REMARKS}

From a geotectonic viewpoint the Piquiri Syenite Massif, like the Siluro-Ordovician syenites from the Scottish Caledonides referred by Thompson and Fowler (1986), are post-orogenic or post-collisional. The very expressive syenitic magmatism in northeastern Brazil is, at least partially, not temporally related with lithospheric consumption, but most authors have recognized its mantle source as previously affected by subduction. Therefore, a large part of syenites, and probably trachytes as well, are derived from sources modified by subduction in postcollisional or "anorogenic" settings. Rock et al. (1992), in agreement with Middlemost et al. (1988), suggested that a cogenetic continuum exists between minettes and lamproites. The evidence from ultrapotassic syenites and associated lamprophyryc enclaves - minettes - leads to speculate that this continuum should be widened to include the silica-saturated ultrapotassic and shoshonitic magmatism, in agreement with Rogers' (1992, p. 88) statement "...it seems most unlikely that potassium enrichment processes as reflected by the ultrapotassic rocks are specific to this category alone". Therefore, shoshonitic, silica-saturated ultrapotassic, minette and lamproite melts could be envisaged as products of veined peridotic mantle with increasing amounts of phlogopite, apatite, and amphibole. Leucite-bearing ultrapotassic magmas should probably be included near lamproites.

Ultrapotassic syenites and granites may be distinguished from shoshonitic and from other A-type granites mainly by their high $\mathrm{K}_{2} \mathrm{O} / \mathrm{Na}_{2} \mathrm{O}$ ratios, and by their association with ultrapotassic lamprophyres, their presence being evidence for mantle sources affected by a previous lithospheric subduction.

The sources of syenitic magmatism, like the mantle sources of most post-collisional magmatism in southern Brazil (Wildner et al. 2002), are OIB-type sources, and that can be understood from the models for OIB source evolution suggested by Hofmann and White (1982) and re-emphasized by Davies (2002).

\section{ACKNOWLEDGMENTS}

This research was supported by Conselho Nacional de Desenvolvimento Científico e Tecnológico (CNPq) through Programa de Apoio a Núcleos de Excelência (PRONEX $N^{\circ}$ 04/0825-3) and Universal funding programs.

\section{RESUMO}

O Maciço Sienítico Piquirí, situado no extremo sul do Brasil, é parte do magmatismo pós-colisional neoproterozóico relacionado ao Ciclo Brasiliano-Pan-Africano. O maciço tem em 
torno de $12 \mathrm{~km}$ de diâmetro e é composto de sienitos, granitos, rochas monzoníticas e lamprófiros. Diopsídio-flogopita, diopsídio-biotita-augita- anfibólio cálcico são as principais paragêneses ferromagnesianas nas rochas sieníticas. As rochas sieníticas e graníticas são co-magmáticas e relacionadas ao magmatismo ultrapotássico saturado em sílica. Seus padrões de elementos traços indicam fontes mantélicas previamente afetadas por metassomatismo relacionado com subducção litosférica. Os granitos ultrapotássicos deste maciço foram produzidos por cristalização fracionada a partir de magmas sieníticos e podem ser considerados como representantes de um grupo particular de granitos subsolvus e hipersolvus, ultrapotássicos, do tipo A. Evidências texturais, estruturais e geoquímicas indicam que as rochas do maciço, principalmente os tipos de granulação fina, representam líquidos magmáticos, embora mostrem abundantes feições de acumulação e segregação magmática, como schlieren, fragmentos de cumulados precoces e bandamento composicional. A maior parte das amostras estudadas é metaluminosa com razões $\mathrm{K}_{2} \mathrm{O} / \mathrm{Na}_{2} \mathrm{O}$ superiores a 2. Os magmas sieníticos e lamprofíricos que originaram o maciço são interpretados como provenientes de fontes mantélicas enriquecidas, do tipo OIB, como admitido para a maior parte do magmatismo pós-colisional shoshonítico, alcalino sódico e toleítico alto $\mathrm{K}$ do sul do Brasil. Essas fontes são provavelmente porções do manto venulado, com abundante flogopita + apatita + anfibólio que refletem o efeito de um prévio metassomatismo causado por fluídos relacionados com subducção litosférica.

Palavras-chave: magmatismo pós-colisional, sienitos ultrapotássicos, granitos ultrapotássicos, magmatismo do tipo A, Maciço Sienítico Piquirí.

\section{REFERENCES}

Babinski M, Chemale JR F, van Schmus W, HartMANN LA AND SILVA LC. 1997. U-Pb and Sm-Nd geochronology of the Neoproterozoic granitic-gneissic Dom Feliciano Belt, Southern Brazil. J South Am Earth Sci 10: 263-274.

Bitencourt MF AND NARdi LVS. 2000. Tectonic setting and sources of magmatism related to the Southern Brazilian Shear Belt. Rev Bras Geoc 30: 184-187.

BITENCOURT MF AND NARDI LVS. 2004. The role of xenoliths and flow segregation in the genesis and evolution of the Paleoproterozoic Itapema Granite, a crustally derived magmas of shoshonitic affinity from southern Brazil. Lithos 73: 1-19.
BONIN B AND GIRET A. 1984. The plutonic alkaline series: the problem of their origin and differentiation, the role of their mineralogical assemblages. Phys Earth Planet Int 35: 212-221.

Bourne JH AND L'Heureux M. 1991. The petrography and geochemistry of the Clericy Pluton: an ultrapotassic pyroxenite-syenite suite of late Archaean age from the Abitibi region, Quebec. Precamb Res 52: 37-51.

BROWN GC. 1981. Calc-alkaline intrusive rocks: their diversity, evolution, and relation to volcanic arcs. In: THORPE, RS (Ed), Andesites. JWiley \& Sons, London, p. 437-460.

CARmichael ISE, LAnge RA And Luhr JF. 1996. Quaternary minettes and associated volcanic rocks of Mascota, western Mexico: a consequence of plate extension above a subduction modified mantle wedge. Contrib Mineral Petrol 124: 302-333.

Chemale JR F. 2000. Evolução Geológica do Escudo Sulrio-grandense. In: Holz M AND DE Ros LF (Eds), Geologia do Rio Grande do Sul, Volume Especial do CIGO/ UFRGS, Porto Alegre, RS, Brasil, p. 13-52.

Civetta L, Innocenti F, Manetti P, Peccerillo A AND POLI G. 1981. Geochemical characteristics of potassic volcanics from Mts. Ernici (Southern Latium, Italy). Contrib Mineral Petrol 78: 37-47.

CONCEIÇÃo H. 1993. Petrology of the syenites from the Salvador-Curaça Mobile belt (Bahia - Brazil): Geodynamic significance. An Acad Bras Cienc 65: 17-32.

CONCEIÇÃo H, Oliveira OMC, MARTIN H, Rosa MLS, CONCEIÇÃo RV, PlÁ CID J. 1997. Petrologia do magmatismo alcalino potássico com afinidade lamprofírica e assinatura de subducção no sul do estado da Bahia: Maciço Sienítico de Anuri. Geochim Bras 11: 171-186.

CONCEIÇÃo H, Burgos CMG, Rios DC, Rosa MLS, Cruz filho Be, Peixoto AA, Oliveira ll, MARINHO MM, MACAMBIRA MJB AND SCHELlER T. 2000a. Stocks de K-sienitos pós-orogênicos com assinatura de subducção e afinidade com minettes na parte sudoeste do Núcleo Serrinha (Estado da Bahia): petrografia, idade e litogeoquímica. Geochim Bras 14: 115-134.

CONCEIÇÃo RV AND GREen DH. 2004. Derivation of potassic (shoshonitic) magmas by decompression melting of phlogopite+pargasite lherzolite. Lithos 72: 209-229.

CONCEIÇÃo RV, CONCEIÇÃo H AND LAFON JM. 1997. Petrologia dos sienitos alcalinos potássicos do Maciço de Santanápolis, Ba. Geochim Bras 11: 133-152.

CONCEIÇÃO RV, NARDI LVS AND CONCEIÇÃO H. 2000b. The Santanápolis Syenite: genesis and evolution of 
Paleoproterozoic shoshonitic syenites in northeastern Brazil. Int Geol Rev 42: 1-17.

Corriveau L and Gorton MP. 1993. Coexisting K-rich alkaline and shoshonitic magmatism of arc affinities in the Proterozoic: a ressessment of syenitic stocks in the southwestern Greenville Province. Contrib Mineral Petrol 113: 262-279.

DAVIES GF. 2002. Stirring geochemistry in mantle convection models with stiff plates and slabs. Geochim Cosmochim Acta 66: 3125-3142.

de Astis GD, Peccerillo A, Kemton PD, Volpe LL AND WU TW. 2000. Transition from calc-alkaline to potassium-rich magmatism in subduction environments: geochemical and $\mathrm{Sr}, \mathrm{Nd}, \mathrm{Pb}$ isotopic constraints from the island of Vulcano (Aeolian Arc). Contrib Mineral Petrol 139: 684-703.

De la Roche H, Leterrier J, Granclaude P And MARCHAL M. 1980. A classification of volcanic and plutonic rocks using R1 R2 diagrama and major element analyses. Its relationships with current nomenclature. Chem Geol 29: 183-210.

Eklund O, Konopelko D, Rutansen H, FröJdö C AND ShebANOV AD. 1998. 1.8 Ga Svelojennaina post collisional shoshonitic magmatism in Fennoscandia Shield. Lithos 45: 87-108.

EVEnSEN NM, HAMilton PJ AND O'NiONS RK. 1978. Rare earth abundances in chondritic meteorites. Geochim Cosmochim Acta 42: 1199-1212.

Feldstein SN AND LANGe R. 1999. Pliocene potassic magmas from the Kings River region, Sierra Nevada, California: evidence for melting of a subduction-modified mantle. J Petrol 40: 1301-1320.

Fernandes LAD, TOMmasi A AND PorCher CC. 1992. Deformation patterns in the southern Brazilian branch of the Dom Feliciano Belt: A reappraisal. J South Am Earth Sci 5: 77-96.

FERREIRA VP AND SiAL AN. 1993. Mica pyroxenite as probable source fro ultrapotassic and potassic magmas in northeastern Brazil. An Acad Bras Cienc 65: 51-61.

FOLEY SF. 1992. Vein-plus-wall-rock melting mechanisms in the lithosphere and the origin of potassic alkaline magmas. Lithos 28: 435-453.

Foley SF, Venturelli G, Green DH and Toscani L. 1987. The ultrapotassic rocks: Characteristics, Classification, and Constraints for petrogenetic models. Earth Sci Rev 24: 81-134.

Hartmann LA, NARdi LVS, Formoso MLL, Remus
MVD, Lima EF AND Mexias A. 1999. Magmatism and metallogeny in the crustal evolution of Rio Grande do Sul Shield, Brazil. Pesquisas 26: 45-63.

Hofmann AW And White WM. 1982. Mantle plumes from ancient oceanic crust. Earth Planet Sci Let 57: $421-436$.

Holm PM, Lou S ANd Nielsen A. 1982. The geochemistry and petrogenesis of the lavas of the Vulsinian District, Roman Province, Central Italy. Contrib Mineral Petrol 80: 367-378.

Ilbeyli N, Pearce JA, Thirlwall MF and Mitchell JG. 2004. Petrogenesis of collision- related plutonics in Central Anatolia, Turkey. Lithos 72: 163-182.

JANASI VA, VlaCh SRF AND Ulbrich HHGJ. 1993. Enriched-mantle contributions to the Itu Granitoid Belt, Southeastern Brazil: evidence from K-rich diorites and syenites. An Acad Bras Cienc 65: 107-118.

JefFery PG AND HutChison D. 1981. Chemical methods of rock analysis. $3^{\text {rd }}$ ed., Oxford, Pergamon Press, 379 p.

Jost H, Brod JA, Holz M, Kuhn A, Flor MAD, Kronbauer A And Dillenburg S. 1985. Geologia estrutural, petrografia e petrologia do sienito Piquiri (Proterozóico Superior), Rio Grande do Sul. In: ANAIS DO Simpósio Sul-brasileiro de Geologia 2, Florianópolis, SC, Brasil, SBG, p. 63-80.

Kay RW And Mahlburg-Kay S. 1991. Creation and destruction of lower continental crust. Geol Rund 80: 259278.

LAflèche MR, Dupuy C And Dostal J. 1991. Archaean orogenic ultrapotassic magmatism: an example from the southern Abitibi greenstone belt. Precamb Res 52: 71-96.

LAMEYRE J AND Bowden P. 1982. Plutonic rocks type series: discrimination of various granitoid series and related rocks. J Volcanol Geother Res 14: 169-186.

LE MAitRe RW. 2002. Igneous Rocks - A classification and Glossary of Terms. Cambridge University Press, Cambridge. $236 \mathrm{p}$.

LEAT PT, JACKSON SE, ThORPE RS AND STILlman CJ. 1986. Geochemistry of bimodal basalt-subalkaline/peralkaline rhyolite provinces within the southern British Caledonides. J Geol Soc London 143: 259-273.

LEAT PT, THOMPSON RN, MORRISON MA, HENDRY GL AND DICKIN MA. 1989. Silicic magmas derived by fractional crystallization from Miocene minettes, Elkhead Mountains, Colorado. Mineral Mag 52: 577-585.

LiÉGEOIS JP. 1998. Preface-Some words on the postcollisional magmatism. Lithos 45: xv-xvii. 
LIMA EF AND NARDi LVS. 1998a. The Lavras do Sul Shoshonitic Association: implications for the origin and evolution of Neoproterozoic shoshonitic magmatism southernmost Brazil. J South Am Earth Sci 11: 67-77.

LIMA EF AND NARDI LVS. 1998b. Química mineral das rochas vulcânicas e lamprófiros espessartíticos da Associação Shoshonítica de Lavras do Sul-RS. Rev Bras Geoc 28: 113-124.

Lloyd FE, ARIMA M AND Edgar AD. 1985. Partial melting of a phlogopite-clinopyroxenite nodule from southwest Uganda: an experimental study bearing on the origin of highly potassic continental rift volcanics. Contrib Mineral Petrol 91: 321-329.

Melzer S AND Foley SF. 2000. Phase relations and fractionation sequences in potassic magma series modeled in the system $\mathrm{CaMgSi}_{2} \mathrm{O}_{6}-\mathrm{KAlSiO}_{4}-\mathrm{Mg}_{2} \mathrm{SiO}_{4}-\mathrm{SiO}_{2}-\mathrm{F} 2 \mathrm{O}_{-1}$ at 1 bar to 18 kbar. Contrib Mineral Petrol 138: 186-197.

Middlemost EAK, Paul DK and Fletcher IR. 1988. Geochemistry and mineralogy of the minette-lamproite association from the Indian Gondwanas. Lithos 22: 31-42.

Miller C, Schuster R, Klötzliu, Frank W And Purtscheller F. 1999. Post-collisional potassic and ultrapotassic magmatism in SW Tibet: Geochemical and $\mathrm{Sr}-\mathrm{Nd}-\mathrm{Pb}-\mathrm{O}$ isotopic constraints for mantle source characteristics and petrogenesis. J Petrol 40: 1399-1424.

MORRISON GW. 1980. Characteristics and tectonic setting of the shoshonite rocks association. Lithos 13: 97-108.

Mullen ED. 1983. $\mathrm{MnO} / \mathrm{TiO}_{2} / \mathrm{P}_{2} \mathrm{O}_{5}$ : a minor element discriminant for basaltic rocks of oceanic environments and its implications for petrogenesis. Earth Planet Sci Let 62: 53-62.

NAChit H, RAZAFImAheFA N, STUSSi JM AND CARRON JP. 1985. Composition chimique des biotites et typologie magmatique des granitoides. CR Acad Sci Paris, Sér II 301: 813-818.

NARdi LVS AND Bonin B. 1991. Post orogenic and non orogenic alkaline granite associations: the Saibro Intrusive Suite, Southern Brasil: a case study. Chem Geol 92: 197-212.

NARdi LVS, Plá Cid J And Bitencourt MF. 2007. Geochemistry of mafic microgranular enclaves and their relationship with the host syenite within the mantle pressure lamprophyre-syenite systems (Piquiri Massif) of Southern Brazil. Mineral Petrol 91: 101-116.

NeKVASIL H. 1990. Reaction relations in the granite system: Implications for trachytic and syenitic magmas. Am Mineral 75: 560-571.
NEKVASIL H. 1992. Ternary feldspar crystallization in hightemperature felsic magmas. Am Mineral 77: 592-604.

PAim M, Plá Cid J, Rosa ML, CONCEICÃo H AND NARdi LVS. 2002. Mineralogy of lamprophyres and mafic enclaves associated to the Paleoproterozoic Cara Suja Syenite, NE Brazil. Int Geol Rev 44: 1017-1036.

PEARCE JA. 1982. Trace element characteristcs of lavas from destructive plate boundaries. In: THORPE RS (ED), Andesites Orogenic, Andesites and Related Rocks: Chichester, UK, J Wiley \& Sons, p. 525-548.

Pearce TH, Gorman BE and Birkett TC. 1977. The relationship between major element chemistry and tectonic environment of basic and intermediate volcanic rocks. Earth Planet Sci Let 36: 121-132.

PhILIPP RP, MACHAdo R, NARdi LVS AND LAFON JM. 2002. O magmatismo granítico neoproterozóico do Batólito Pelotas no sul do Brasil: novos dados e revisão da geocronologia regional. Rev Bras Geoc 32: 277-290.

PlÁ CID J AND NARDi LVS. 2006. Alkaline ultrapotassic Atype granites derived from ultrapotassic syenite magmas generated at metasomatised mantle sources. Int Geol Rev 48: $942-956$.

Plá Cid J, Nardi LVS, Conceição H And Bonin B. 1999. Petrogenesis of the Neoproterozoic alkaline ultrapotassic suites of northeastern Brazil: major- and traceelement evidence from pyroxene chemistry and numerical modelling. Int Geol Rev 41: 1005-1027.

Plá Cid PJ, NARdi LVS, CONCEIÇão H, Bonin B AND JARDIM DE SÁ E. 2000. The alkaline silica-saturated ultrapotassic magmatism of the Riacho do Pontal Fold Belt, NE Brazil: an example of syenite-granite Neoproterozoic association. J South Am Earth Sci 13: 661-683.

Plá Cid J, Nardi lVS, Stabel LZ, Conceição RV AND BALZARETTI NM. 2003. High-pressure minerals in mafic microgranular enclaves: evidences for co-mingling between lamprophyric and syenitic magmas at mantle conditions. Contrib Mineral Petrol 145: 444-459.

Plá Cid J, Nardi lVS, Enrique P, Merlet C and BOYER B. 2005. SIMS analysis on trace and rare earth elemens in coexisting clinopyroxene and mica from minette mafic enclaves in potassic syenites crystallized under high pressures. Contrib Mineral Petrol 148: 675-688.

Rock NMS. 1987. The nature and origin of lamprophyres: an overview. In: FITTON JG AND UPTON BGJ (Eds), Alkaline igneous rocks. Geol Soc Spec Publ 30: 191-226.

Rock NMS, Griffin BJ, Edgar AD, PaUl DK AND Hergt JM. 1992. A spectrum of potentially diamondif- 
erous lamproites and minettes from the Jharia coalfield, eastern India. J Volcanol Geother Res 50: 55-83.

Rogers NW. 1992. Potassic magmatism as a key to traceelement enrichment processes in the upper mantle. J Volcanol Geother Res 50: 85-99.

Silva Filho AF, Thompson RN and Leat PT. 1987. Petrology of Terra Nova Pluton, Brazil, and associated ultrapotassic dikes. Rev Bras Geoc 17: 481-487.

Silva Filho AF, Guimarães IP ANd Thompson RN. 1993. Shoshonitic and ultrapotassic Proterozoic intrusive suites in the Cachoeirinha-Salgueiro belt, NE Brazil: a transition from collisional to post-collisional magmatism. Precamb Res 62: 323-342.

Soliani Jr E, Koester E And Fernandes LAD. 2000. A geologia isotópica do Escudo Sul-rio-grandense - Parte I: métodos isotópicos e valor interpretativo. In: HoLZ M And Deros LF (Eds), Geologia do Rio Grande do Sul. Volume Especial do CIGO/UFRGS. Porto Alegre, RS, Brasil, p. 175-230.

Sommer C, Lima EF AND NARdi LVS. 1999. O vulcanismo alcalino do Platô do Taquarembó, Dom Pedrito, RS. Rev Bras Geoc 29: 245-254.

Stabel LZ, NARdi LVS AND Plá Cid J. 2001. Química mineral e evolução petrológica do Sienito Piquiri: magmatismo shoshonítico, neoproterozóico, pós-colisional no sul do Brasil. Rev Bras Geoc 31: 211-222.

Stormer JC ANd Nicholls J. 1978. XLFRAC: A program for the interactive testing of magmatic differentiation models. Comput Geosci 4: 143-159.

SUN SS. 1980. Lead isotopic study of young volcanic rocks from mid-ocean ridges, ocean islands and island arcs. Phil Trans R Soc A297: 409-445.
TAUSON LV. 1983. Geochemistry and metallogeny of the latitic series. Int Geol Rev 25: 125-135.

THOMPSON RN AND FOWLER MB. 1986. Subduction-related shoshonitic and ultrapotassic magmatism: a study of Siluro-Ordovician syenites from the Scottish Caledonides. Contrib Mineral Petr 94: 507-522.

Vieira Jr N, Fernandes LAD, Koester E and ScheRER CS. 1989. Enclaves Microgranulares do Maciço de Piquiri - RS. Acta Geol Leopold 29: 185-206.

WATSON EB AND HARRISON TM. 1983. Zircon saturation revisited: temperature and composition effects in a variety of crustal magma types. Earth Planet Sci Let 64: 295-304.

Wildner W, NARdi LVS ANd Lima EF. 1999. Post-Collisional Alkaline Magmatism on the Taquarembó Plateau: A Well Preserved Neoproterozoic-Cambrian Plutono-Volcanic Association In Southern Brazil. Int Geol Rev 41: 1082-1098.

Wildner W, Lima EF, NARdi LVS And Sommer CA. 2002. Volcanic Cycles and Setting in the Neoproterozoic III to Ordovician Camaquã Basin Succession in Southern Brazil: Characteristics of Post-Collisional Magmatism. J Volcanol Geother Res 2495: 1-23.

Winchester JA AND Floyd PA. 1977. Geochemical discrimination of different magma series and theiur differentiation products using immobile elements. Chem Geol 20: 325-343.

Wood DA. 1980. The application of a Th-Hf-Ta diagram to problems of tectonomagmatic classification and to establishing the nature of crustal contamination of basaltic lavas of the British Tertiary Volcanic Province. Earth Planet Sci Let 50: 11-30. 